\title{
Characterization of pyrimidine nucleoside phosphorylase of Mycoplasma hyorhinis: implications for the clinical efficacy of nucleoside analogues
}

\author{
Johan VANDE VOORDE* ${ }^{*}$ Federico GAG0 $\dagger$, Kristof VRANCKEN*, Sandra LIEKENS ${ }^{\star 1}$ and Jan BALZARINI*1 \\ *Rega Institute for Medical Research, KU Leuven, Minderbroedersstraat 10, blok x - bus 1030, B-3000 Leuven, Belgium, and †Departamento de Farmacología, Universidad de Alcalá, \\ E-28871 Alcalá de Henares, Madrid, Spain
}

In the present paper we demonstrate that the cytostatic and antiviral activity of pyrimidine nucleoside analogues is markedly decreased by a Mycoplasma hyorhinis infection and show that the phosphorolytic activity of the mycoplasmas is responsible for this. Since mycoplasmas are (i) an important cause of secondary infections in immunocompromised (e.g. HIV infected) patients and (ii) known to preferentially colonize tumour tissue in cancer patients, catabolic mycoplasma enzymes may compromise efficient chemotherapy of virus infections and cancer. In the genome of $M$. hyorhinis, a TP (thymidine phosphorylase) gene has been annotated. This gene was cloned, expressed in Escherichia coli and kinetically characterized. Whereas the mycoplasma TP efficiently catalyses the phosphorolysis of thymidine $\left(K_{\mathrm{m}}=473 \mu \mathrm{M}\right)$ and deoxyuridine $\left(K_{\mathrm{m}}=578 \mu \mathrm{M}\right)$, it prefers uridine $\left(K_{\mathrm{m}}=92 \mu \mathrm{M}\right)$ as a substrate. Our kinetic data and sequence analysis revealed that the annotated $M$. hyorhinis TP belongs to the NP (nucleoside phosphorylase)-II class PyNPs (pyrimidine NPs), and is distinct from the NP-II class TP and NPI class UPs (uridine phosphorylases). M. hyorhinis PyNP also markedly differs from TP and UP in its substrate specificity towards therapeutic nucleoside analogues and susceptibility to clinically relevant drugs. Several kinetic properties of mycoplasma PyNP were explained by in silico analyses.

Key words: antiviral/anticancer activity, Mycoplasma hyorhinis, nucleoside analogue, pyrimidine nucleoside phosphorylase (PyNP), thymidine phosphorylase (TP), uridine phosphorylase (UP).

\section{INTRODUCTION}

The treatment of cancer and many viral infections [caused by e.g. HIV, HSV (herpes simplex virus), Varicella Zoster virus, cytomegalovirus, hepatitis $\mathrm{C}$ virus or hepatitis $\mathrm{B}$ virus] is largely based on the use of nucleoside-derived therapeutics $[1,2]$. These molecules mimic the nucleic acid building blocks and may therefore act as antimetabolites in DNA/RNA synthesis or as fraudulent substrates for enzymes involved in nucleoside metabolism. Thus, after enzymatic activation (usually phosphorylation), they directly or indirectly interfere with the cellular or viral DNA/RNA synthesis. Owing to the nature of these drugs they may also be subject to enzymatic inactivation (e.g. deamination, phosphorolysis or dephosphorylation) by enzymes involved in nucleo(s)(t)ide catabolism. It has previously been demonstrated that mycoplasma-derived TP (thymidine phosphorylase) activity compromises the cytostatic action of several nucleoside-based chemotherapeutics in cancer cell cultures [3-6].

Mycoplasmas are the smallest autonomously replicating organisms and are characterized by the lack of a cell wall and a strongly reduced genome (600-1200 kb). Many of these bacteria, belonging to the class of the Mollicutes, have a parasitic lifestyle and reside in the human body causing asymptomatic infections [7]. In particular immunocompromised patients (e.g. patients suffering from AIDS or hypogammaglobulinaemia) are known to be prone to mycoplasma infections $[8,9]$. Despite their high tissue specificity, mycoplasmas are now regularly being isolated from organs different from their usual habitats owing to the increasing number of patients suffering such immunodeficiencies [7]. Furthermore, it was shown that some of these prokaryotes, in particular Mycoplasma hyorhinis, tend to preferentially colonize tumour tissue in cancer patients [10-17]. Taken together, these studies indicate that a mycoplasma infection may not only affect the health of cancer patients or immunocompromised individuals, but may also compromise the efficacy of chemotherapeutic treatment.

Previously, we hypothesized that the treatment of patients using purine and pyrimidine antimetabolite drugs may be optimized by (i) the elimination of an underlying mycoplasma infection by antibiotics, (ii) suppression of mycoplasma-encoded enzymes in human tumour tissue and/or (iii) the development of mycoplasmainsensitive nucleoside analogue prodrugs $[5,6,18]$. In the absence of such approaches, cancer patients may receive suboptimal chemotherapeutic treatment. In the present paper, we demonstrate that the M. hyorhinis-derived phosphorolytic activity in cell cultures is not only responsible for the decreased cytostatic activity of certain nucleoside analogues, but also for their decreased antiviral activity towards different human viruses. To gain further insight into the molecular basis of these observations, we cloned, expressed and characterized the putative $M$. hyorhinisencoded TP. The kinetic properties of this enzyme shed new light on pyrimidine nucleoside metabolism in Mollicutes and reveal a distinct substrate specificity when compared with human or Escherichia coli TP and UP [Urd (uridine) phosphorylase]. Structural and functional studies revealed two distinct families of NPs (nucleoside phosphorylases): the NP-I family (containing purine NP and UP) and the NP-II family [containing TP and

Abbreviations used: ara-T, thymine arabinoside; ara-U, uracil arabinoside; AZT, azidothymidine; BAU, 5-benzylacyclouridine; BVDU, (E)-5(2-bromovinyl)-deoxyuridine; BVU, (E)-5-(2-bromovinyl)-uracil; 2-dRib-1-P, 2-deoxyribose-1-phosphate; D4T, stavudine; dThd, thymidine; dUrd, 2'deoxyuridine; 7-DX, 7-deazaxanthine; 5-FU, 5-fluorouracil; GST, glutathione transferase; HSV, herpes simplex virus; NP, nucleoside phosphorylase; PyNP, pyrimidine nucleoside phosphorylase; Rib-1-P, ribose-1-phosphate; TFT, 5-trifluoromethyl-dUrd; Thy, thymine; TP, thymidine phosphorylase; TPI, TP inhibitor; UP, uridine phosphorylase; UPP1, human UP1; Ura, uracil; Urd, uridine; VV, vaccinia virus.

1 Correspondence may be addressed to either of these authors (email jan.balzarini@rega.kuleuven.be or sandra.liekens@rega.kuleuven.be). 
PyNPs (pyrimidine NP)] [19]. Our kinetic and computational sequence analysis data demonstrate that the mycoplasma-encoded TP activity is due to the presence of an NP-II class PyNP in the cell cultures that is distinct from the NP-II class TP and NP-I class UP enzymes. Our findings explain the dramatic effect mycoplasmas may have on the antiviral and cytostatic efficiency of several chemotherapeutics in infected human cell cultures.

\section{EXPERIMENTAL}

\section{Chemicals}

Nucleosides, nucleobases, nucleoside analogues and all of the inorganic compounds were purchased from Sigma-Aldrich unless stated otherwise. TPI $\{\mathrm{a}$ potent TP inhibitor/5-chloro-6-(1[2-iminopyrrolidinyl]methyl)Ura hydrochloride, where Ura is uracil $\}$ [20] was kindly provided by Professor Vern Schramm (Albert Einstein College of Medicine, New York, NY, U.S.A.). BAU (5-benzylacyclouridine) was purchased from RNDCHEM. 7-DX (7-deazaxanthine) was synthesized as described previously [21].

\section{Cell cultures}

MCF-7 human breast carcinoma cells were kindly provided by Professor Godefridus Peters (VU University Medical Center, Amsterdam, The Netherlands). MCF-7 cells were infected with $M$. hyorhinis (strain number A.T.C.C. 17981) resulting in a chronically infected cell line henceforth referred to as MCF7.Hyor. All of the cells were maintained in DMEM (Dulbecco's modified Eagle's medium; Invitrogen) with $10 \%$ foetal bovine serum (Biochrom), $10 \mathrm{mM}$ Hepes and $1 \mathrm{mM}$ sodium pyruvate (Invitrogen). Cells were grown at $37^{\circ} \mathrm{C}$ in a humidified incubator with a gas phase of $5 \% \mathrm{CO}_{2}$.

\section{Biological assays}

The antiviral assays were based on inhibition of virus-induced cytopathicity in MCF-7 and MCF-7.Hyor cell cultures. Cells were seeded in 96-well plates (Thermo Fisher Scientific) at 20000 cells/well and were allowed to proliferate for $24 \mathrm{~h}$ at $37^{\circ} \mathrm{C}$. The cells were then exposed to fresh medium containing 100 CCID50 (50\% cell culture infectious dose) of virus [VV (vaccinia virus), HSV-1 (strain KOS), or HSV-2 (strain G)] and different concentrations of the test compound in the presence or absence of TPI $(10 \mu \mathrm{M})$. The cells were incubated at $37^{\circ} \mathrm{C}$ and viral cytopathicity was recorded as soon as it reached completion in the control virus-infected cell cultures that were not treated with the test compounds. In addition, the antiviral activity of 5-iododUrd (where dUrd is 2'-deoxyuridine) against VV was compared in MCF-7 and MCF-7.Hyor cells that were pretreated for 4 days with $1 \mu \mathrm{g} / \mathrm{ml}$ tetracycline, an antibiotic targeting mycoplasmas.

To compare the cytostatic activity of nucleoside analogues in mycoplasma-infected and control cancer cell lines, MCF-7 and MCF-7.Hyor cells were seeded in 48-well plates (Thermo Fisher Scientific) at 10000 cells/well. After $24 \mathrm{~h}$, an equal volume of fresh medium containing the test compounds was added. On day 5 , cells were trypsinized and counted in a Coulter counter. The $\mathrm{IC}_{50}$ value was defined as the compound concentration required to reduce cell proliferation by $50 \%$.

\section{Purification of $\mathrm{TP}_{\mathrm{Hyor}}$ (M. hyorhinis TP)}

In the recently published $M$. hyorhinis HUB-1 genome [22], a TP gene, but no UP gene, was found. Therefore a codonoptimized DNA sequence encoding the $\mathrm{TP}_{\text {Hyor }}$ was synthetically assembled between the EcoRI and NotI restriction sites of a pIDTsmart vector (Integrated DNA technologies). The fragment was subsequently subcloned between the EcoRI and NotI sites of the pGEX-5X-1 bacterial expression vector (Amersham Pharmacia) and expressed in E. coli BL21(DE3)pLysS as a GST (glutathione transferase) fusion protein according to the procedure described previously [23]. Bacteria were grown for $8 \mathrm{~h}$ at $37^{\circ} \mathrm{C}$ in $\mathrm{LB}$ (Luria-Bertani) medium containing ampicillin $(100 \mu \mathrm{g} / \mathrm{ml})$ and chloramphenicol $(40 \mu \mathrm{g} / \mathrm{ml})$, diluted $1: 30$ in fresh medium and grown overnight under the same conditions. Next, the culture was diluted 1:10 in fresh medium and incubated for $2 \mathrm{~h}$ at $37^{\circ} \mathrm{C}$. Then cultures were placed at $27^{\circ} \mathrm{C}$ for $4 \mathrm{~h}$ after which IPTG (isopropyl- $\beta$-D-thiogalactopyranoside) was added to a final concentration of $0.1 \mathrm{mM}$ to induce the production of the GST-TP fusion protein. After $15 \mathrm{~h}$ of further growth at $27^{\circ} \mathrm{C}$, cells were pelleted $\left(6000 \mathrm{~g}\right.$ for $10 \mathrm{~min}$ at $\left.4^{\circ} \mathrm{C}\right)$ and resuspended in lysis buffer [50 mM Tris/ $\mathrm{HCl}(\mathrm{pH} 7.5), 1 \mathrm{mM}$ dithiothreitol, $5 \mathrm{mM}$ EDTA, $10 \%$ glycerol, $1 \%$ Triton X-100, $0.1 \mathrm{mM}$ PMSF and $0.15 \mathrm{mg}$ of lysozyme]. Bacterial suspensions were homogenized and lysed by means of a French Pressure cell press and ultracentrifuged $(20000 \mathrm{rev} / \mathrm{min}$ for $15 \mathrm{~min}$ at $4{ }^{\circ} \mathrm{C}$ using a Beckman Coulter Type $70 \mathrm{~T}$; fixed angle rotor). GST- $\mathrm{TP}_{\mathrm{Hyor}}$ (henceforth referred to as $\mathrm{TP}_{\mathrm{Hyor}}$ ) was purified from the supernatant using glutathione-Sepharose 4B (Amersham Pharmacia) following the manufacturer's instructions. Briefly, a $50 \%$ slurry of glutathione-Sepharose was added to the bacterial supernatant $\left(2 \mathrm{ml} / 750 \mathrm{ml}\right.$ of broth), incubated at $4{ }^{\circ} \mathrm{C}$ and then washed three times with 10 bed volumes of lysis buffer without lysozyme and PMSF. Bound proteins were eluted in $50 \mathrm{mM}$ Tris/ $\mathrm{HCl}(\mathrm{pH} 7.5)$ containing $0.1 \%$ Triton X$100,10 \mathrm{mM}$ glutathione and $20 \%$ glycerol. SDS/PAGE $(10 \%$ gel) revealed a GST-fusion protein of $\sim 75 \mathrm{kDa}$ (48 kDa for $\mathrm{TP}_{\text {Hyor }}$ and $25 \mathrm{kDa}$ for GST) (Supplementary Figure $\mathrm{S} 1$ at http://www.BiochemJ.org/bj/445/bj4450113add.htm).

\section{Enzyme assays}

\section{Determination of the $\mathrm{pH}$ and temperature optima}

The $\mathrm{TP}_{\text {Hyor }}$-mediated phosphorolysis of dThd (thymidine) was assayed under different $\mathrm{pH}$ and temperature conditions. dThd $(100 \mu \mathrm{M})$ was incubated in the presence of the enzyme $(9 \mathrm{nM})$ at $37^{\circ} \mathrm{C}$ with varying $\mathrm{pH}$ buffer conditions $(\mathrm{pH}=5.5-8.5)$. Reactions were carried out in a total volume of $500 \mu \mathrm{l}$ of phosphorolysis buffer (10 mM Tris/HCl, $1 \mathrm{mM}$ EDTA, $150 \mathrm{mM}$ $\mathrm{NaCl}$ and $200 \mathrm{mM}$ potassium phosphate). At different time points $(0,20,40$ and $60 \mathrm{~min}), 100 \mu \mathrm{l}$ fractions were withdrawn, transferred to an Eppendorf tube and heated at $95^{\circ} \mathrm{C}$ for 3 min to inactivate the enzyme. Next, the samples were rapidly cooled on ice for $15 \mathrm{~min}$ and cleared by centrifugation at $16000 \mathrm{~g}$ for $15 \mathrm{~min}$. Thy (thymine) was separated from dThd on a reverse phase RP8 column (Merck) and quantified by HPLC analysis (Alliance 2690, Waters). The separation was performed by a gradient from $100 \%$ buffer $\mathrm{B}\left[50 \mathrm{mM} \mathrm{NaH} \mathrm{PO}_{4}\right.$ (Acros Organics) and $5 \mathrm{mM}$ heptane sulfonic acid (pH 3.2)] to $75 \%$ buffer $\mathrm{B}$ and $25 \%$ acetonitrile (BioSolve) (10 min linear gradient of $100 \%$ buffer B to $98 \%$ buffer $\mathrm{B}$ and $2 \%$ acetonitrile; 10 min linear gradient to $90 \%$ buffer B and $10 \%$ acetonitrile; 5 min linear gradient to $75 \%$ buffer B and $25 \%$ acetonitrile; and 5 min linear gradient to $100 \%$ buffer B followed by equilibration at $100 \%$ buffer B for $10 \mathrm{~min}$ ). UV-based detection of dThd was performed at $266 \mathrm{~nm}$. The $\mathrm{TP}_{\mathrm{Hyor}}$-mediated phosphorolysis of dThd was also compared after incubation at $20^{\circ} \mathrm{C}$ and at $37^{\circ} \mathrm{C}$ in a similar assay carried out in TP buffer [10 mM Tris/HCl, $1 \mathrm{mM}$ EDTA, $150 \mathrm{mM} \mathrm{NaCl}$ and $200 \mathrm{mM}$ potassium phosphate $(\mathrm{pH}$ 7.6)]. 
Determination of $\mathrm{TP}_{\text {Hyor }}$ substrate specificity

To study the phosphorolysis of different nucleosides and nucleoside analogues by $\mathrm{TP}_{\mathrm{Hyor}}$, different potential substrates $(100 \mu \mathrm{M})$ were exposed to the enzyme $(45 \mathrm{nM})$ and incubated at $37^{\circ} \mathrm{C}$ in TP buffer in a total volume of $300 \mu \mathrm{l}$. At different time points $(0,10,30$ and $60 \mathrm{~min}), 65 \mu \mathrm{l}$ fractions were withdrawn, transferred and processed as described above. Nucleobases and nucleosides were separated by HPLC analysis as described above and for each product UV-based detection was performed at the specific wavelength of optimal absorption. Separation of BVDU $[(E)-5$-(2-bromovinyl)-dUrd] from its respective base BVU $[(E)$ 5-(2-bromovinyl)-Ura] was performed by a linear gradient from $98 \%$ buffer C [1 mM potassium phosphate buffer, ( $\mathrm{pH}$ 5.5)] and $2 \%$ buffer $\mathrm{D}[1 \mathrm{mM}$ potassium phosphate buffer ( $\mathrm{pH} 5.5)$ and $80 \%$ methanol] to $20 \%$ buffer $\mathrm{C}$ and $80 \%$ buffer $\mathrm{D}$. After injection of the samples, $98 \%$ buffer $\mathrm{C}$ and $2 \%$ buffer $\mathrm{D}$ was run for $10 \mathrm{~min}$ before the start of the gradient (10 min linear gradient from $2 \%$ to $80 \%$ buffer D). After 5 min running at $80 \%$ buffer $\mathrm{D}$, a 5 min linear gradient to $98 \%$ buffer $\mathrm{C}$ and $2 \%$ buffer D was performed followed by equilibration at $98 \%$ buffer $\mathrm{C}$ for $5 \mathrm{~min}$.

\section{Kinetic assays}

The enzymatic activity of $\mathrm{TP}_{\mathrm{Hyor}}$ towards different substrates (dThd, dUrd, Urd, 5-fluoro-dUrd, 5-iodo-dUrd, 5-fluoro-Urd and 5-iodo-Urd) was evaluated. The nucleoside-to-nucleobase conversion at varying concentrations of substrate was studied in a reaction containing $9 \mathrm{nM}$ enzyme incubated in TP buffer at $37^{\circ} \mathrm{C}$ for $20 \mathrm{~min}$. For each substrate, at least 10 different concentrations in the following range were assayed: dThd and dUrd, 100-6000 $\mu \mathrm{M}$; Urd, 25-2000 $\mu \mathrm{M}$; 5-fluoro-dUrd, 25-1000 $\mu \mathrm{M}$; and 5-iodo-dUrd, 5-fluoro-Urd and 5-iodoUrd, 25-500 $\mu \mathrm{M}$. In the kinetic assays where the enzymatic activity of $\mathrm{TP}_{\mathrm{Hyor}}$ was evaluated at varying concentrations of $\mathrm{P}_{\mathrm{i}}$ (10 different concentrations in the range of $0.1-50 \mathrm{mM}$ ), the nucleoside substrate was kept fixed at a concentration of $10 \times K_{\mathrm{m}}$. After incubation, samples were processed and analysed by HPLC as described above. The Michaelis constant $\left(K_{\mathrm{m}}\right)$ and turnover number $\left(k_{\text {cat }}\right)$ were determined by means of non-linear regression analysis (using GraphPad Prism5).

\section{Competition experiments}

To determine the substrate preference of $\mathrm{TP}_{\mathrm{Hyor}}$, dThd and Urd (each at $100 \mu \mathrm{M}$ ) were exposed in one reaction to $9 \mathrm{nM} \mathrm{TP}{ }_{\text {Hyor }}$. After incubation at $37^{\circ} \mathrm{C}$ in TP buffer, fractions were collected at 0, 20, 40 and $60 \mathrm{~min}$ and processed as described above.

To study whether both substrates are mutually exclusive, $\mathrm{TP}_{\text {Hyor }}$-mediated phosphorolysis of a fixed concentration of dThd $(100 \mu \mathrm{M})$ was studied in the presence of different concentrations of Urd ( $1 \mathrm{mM}, 0.5 \mathrm{mM}, 0.25 \mathrm{mM}, 0.1 \mathrm{mM}$ and $0 \mathrm{mM})$ and vice versa. After a $30 \mathrm{~min}$ incubation of the substrates with the enzyme $(9 \mathrm{nM})$ at $37^{\circ} \mathrm{C}$ in TP buffer, samples were processed as described above.

\section{Anabolic activity of $\mathrm{TP}_{\text {Hyor }}$}

The $M$. hyorhinis TP-mediated coupling of 2-dRib-1-P (2deoxyribose-1-phosphate) to Thy and Ura and the coupling of Rib-1-P (ribose-1-phosphate) to Ura was studied. Sugars $(1 \mathrm{mM})$ and nucleobases $(100 \mu \mathrm{M})$ were incubated at $37^{\circ} \mathrm{C}$

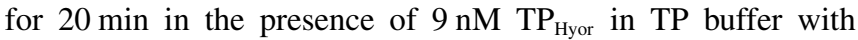
varying concentrations of inorganic phosphate $\left(\mathrm{P}_{\mathrm{i}}=50 \mathrm{mM}\right.$; $5 \mathrm{mM} ; 0.5 \mathrm{mM}$ and $0 \mathrm{mM}$ ) in a total volume of $200 \mu \mathrm{l}$. The formation of dThd and (d)Urd was quantified by HPLC analysis as described above.

\section{Inhibition assays}

In the assays where the inhibitory effect of the TP inhibitors 7DX and TPI and the UP inhibitor BAU was evaluated, a variety of inhibitor concentrations, including $500 \mu \mathrm{M}, 250 \mu \mathrm{M}, 100 \mu \mathrm{M}$, $25 \mu \mathrm{M}$ and $0 \mu \mathrm{M}$ (control), were added to a reaction mixture that contained $100 \mu \mathrm{M}$ substrate (dThd or Urd) in TP buffer containing $2 \mathrm{mM} \mathrm{P} \mathrm{P}_{\mathrm{i}}$. Next, the reaction mixture was exposed to different phosphorolytic enzymes $\left[\mathrm{TP}_{\mathrm{Hyor}}\right.$, human TP, E. coli TP or UPP1 (human UP1; derived from tumour tissue)] and, after a $20 \mathrm{~min}$ incubation at $37^{\circ} \mathrm{C}$, the substrate degradation was determined by HPLC as described above.

\section{Bioinformatics and computational in silico analysis}

Protein alignments and pairwise alignment scores were calculated using ClustalW2 (http://www.ebi.ac.uk/Tools/msa/clustalw2/). The one-to-one threading method implemented in the Phyre 2 server [24] provided different $\mathrm{TP}_{\mathrm{Hyor}}$ models using as templates the three-dimensional structures of several TPs and PyNPs that have been solved by X-ray crystallography and are deposited in the PDB. The computer graphics program PyMOL (http://www.pymol.org/) was used for molecular visualization and superimposition.

\section{RESULTS}

\section{M. hyorhinis infection compromises the biological activity of therapeutic nucleoside analogues}

Human breast carcinoma MCF-7 cells were infected with $M$. hyorhinis (designated MCF-7.Hyor) and used to study the effect of the mycoplasma infection on the antiviral/antiproliferative activity of various nucleoside analogues.

The antiviral activity of 5-halogenated dThd analogues, including the clinically approved antiherpetic agents 5-iodo-dUrd (idoxuridine) and BVDU (Brivudin) against different viruses was determined in MCF-7 and MCF-7.Hyor cell cultures. As shown in Table 1, the inhibitory activity of the drugs against VV, HSV-1 and HSV-2 infection was decreased by 6-55 fold in MCF-7.Hyor cell cultures when compared with mycoplasma-free control MCF-7 cells. The antiviral activity of the compounds could be rescued by pretreating the cells for 4 days with tetracycline $(1 \mu \mathrm{g} / \mathrm{ml})$, an antibiotic targeting mycoplasmas (results not shown). The antiviral activity could also be fully restored upon administration of $10 \mu \mathrm{M}$ TPI, a powerful TP inhibitor (Table 1). Since MCF-7 cells show a very low level of endogenous TP expression (undetectable by Western blot analysis) [25], the data indicate that mycoplasma-encoded TP, expressed in the MCF-7.Hyor cell cultures, is responsible for the decreased antiviral activity of the drugs. In contrast, the activity of BVDU, an antiherpetic agent that is used to treat Varicella Zoster virus infections and known to be an excellent substrate for both human and E. coli-derived TP [26-28], was not compromised in the mycoplasma-infected cell cultures. Instead, BVDU became 5- and 3-fold more inhibitory against VV and HSV-2 respectively in mycoplasma-infected cell cultures, and this increased activity was lost upon addition of TPI.

We also investigated the cytostatic activity of fluoropyrimidines in mycoplasma-infected and -free cell cultures. We previously demonstrated that the decreased cytostatic activity of halogenated dThd analogues could be rescued by elimination of the mycoplasmas using an antibiotic or by the addition of TPI to 
Table 1 Inhibitory activity of dThd analogues against viral infection in MCF-7 and MCF-7.Hyor cells

Results are the means \pm S.D. of two independent experiments.

(a) VV infection

\begin{tabular}{|c|c|c|c|c|}
\hline \multirow[b]{3}{*}{ Compound } & \multicolumn{4}{|l|}{$\underline{E C_{50}(\mu \mathrm{M})}$} \\
\hline & \multicolumn{2}{|l|}{ MCF-7 } & \multicolumn{2}{|l|}{ MCF-7.Hyor } \\
\hline & Alone & $+\mathrm{TPI}$ & Alone & $+\mathrm{TPI}$ \\
\hline 5-Chloro-dUrd & $2.8 \pm 1.1$ & $2.2 \pm 0.7$ & $47.6+4.0$ & $1.6+0.7$ \\
\hline 5-Bromo-dUrd & $1.6 \mp 0.3$ & $1.6 \mp 0.2$ & $48.5+3.3$ & $1.9 \mp 0.1$ \\
\hline 5-lodo-dUrd & $1.8 \pm 0.6$ & $2.9 \pm 1.1$ & $\geqslant 10 \overline{0}$ & $2.7 \pm 1.2$ \\
\hline BVDU & $47.4 \pm 3.7$ & $\geqslant 4 \overline{4} .7$ & $10.2 \pm 1.4$ & $\geqslant 100$ \\
\hline
\end{tabular}

(b) HSV-1 (KOS) infection

\begin{tabular}{|c|c|c|c|c|}
\hline \multirow[b]{3}{*}{ Compound } & \multicolumn{4}{|l|}{$\mathrm{EC}_{50}(\mu \mathrm{M})$} \\
\hline & \multicolumn{2}{|l|}{ MCF-7 } & \multicolumn{2}{|l|}{ MCF-7.Hyor } \\
\hline & Alone & $+\mathrm{TPI}$ & Alone & $+\mathrm{TPI}$ \\
\hline 5-Chloro-dUrd & $7.7 \pm 3.2$ & $8.2 \pm 1.7$ & $44.7 \pm 0$ & $3.5 \pm 1.1$ \\
\hline 5-Bromo-dUrd & $1.5 \pm 0.6$ & $1.5 \pm 0.6$ & $44.7 \pm 0$ & $1.1 \pm 0.4$ \\
\hline 5-lodo-dUrd & $1.8 \pm 0.5$ & $1.9 \pm 0.1$ & $47.6 \pm 4.0$ & $1.3 \pm 0.2$ \\
\hline BVDU & $0.04 \pm 0.02$ & $0.02 \pm 0.006$ & $0.04 \pm 0.03$ & $0.02 \pm 0.01$ \\
\hline
\end{tabular}

(c) HSV-2 (G) infection

\begin{tabular}{lcclll}
\hline & \multicolumn{2}{l}{$\mathrm{EC}_{50}(\mu \mathrm{M})$} & & & \\
\cline { 2 - 3 } & MCF-7 & & & MCF-7.Hyor & \\
\cline { 2 - 3 } \cline { 5 - 6 } Compound & Alone & $+\mathrm{TPI}$ & & Alone & $+\mathrm{TPI}$ \\
\hline 5-Chloro-dUrd & $8.7 \pm 1.4$ & $8.5 \pm 1.9$ & & $51.0 \pm 5.7$ & $1.6 \pm 0.7$ \\
5-Bromo-dUrd & $2.0 \pm 0$ & $1.9 \pm 0.1$ & & $46.6 \pm 3.3$ & $1.9 \pm 0.1$ \\
5-lodo-dUrd & $2.1 \pm 0.2$ & $2.0 \pm 0$ & & $63.1 \pm 31.9$ & $2.0 \pm 0.3$ \\
BVDU & $1.5 \pm 0.6$ & $5.0 \pm 1.7$ & & $0.5 \pm 0.3$ & $4.0 \pm 0$ \\
& & & & & \\
\hline
\end{tabular}

the infected cell cultures [3,6]. The antiproliferative activity of 5-fluorouridine, being a poor substrate for human- or $E$. coli-derived TP and human UPP1 (results not shown), was decreased by 20 -fold in mycoplasma-infected MCF-7.Hyor cells $\left(\mathrm{IC}_{50}=0.226 \pm 0.126 \mu \mathrm{M}\right)$ when compared with control cells $\left(\mathrm{IC}_{50}=0.011 \pm 0.003 \mu \mathrm{M}\right)$. However, the cytostatic activity of this compound could also be fully restored upon administration of TPI $(10 \mu \mathrm{M})$, suggesting that mycoplasmaencoded TP has unique characteristics, distinct from its mammalian and E. coli counterparts, and would deserve further investigation and kinetic characterization.

\section{Determination of substrate specificity of $\mathbf{T P}_{\text {Hyor }}$}

\section{Substrate specificity of $\mathrm{TP}_{\text {Hyor }}$ for natural pyrimidine nucleosides}

The $M$. hyorhinis gene responsible for the TP activity was cloned and the enzyme was expressed and purified as described (see the Experimental section). The phosphorolysis of dThd catalysed by the purified $\mathrm{TP}_{\mathrm{Hyor}}$ was found to be optimal at $\mathrm{pH} 7.5$ (Figure 1A) and at a temperature of $37^{\circ} \mathrm{C}$ (Figure 1B). To determine the substrate specificity of $\mathrm{TP}_{\text {Hyor }}$ towards natural pyrimidine nucleosides, different nucleosides were exposed to the enzyme and phosphorolysis was monitored. $\mathrm{TP}_{\mathrm{Hyor}}$ catalyses the conversion of dThd and dUrd, but also, surprisingly, of Urd into their respective bases (Thy and Ura) and phosphorylated sugars (2-dRib-1-P and Rib-1-P). Neither cytidine nor 2'deoxycytidine were substrates for the enzyme (Table 2$)$. The Michaelis constant $\left(K_{\mathrm{m}}\right)$ and the turnover number $\left(k_{\text {cat }}\right)$ were determined for different substrates using non-linear regression

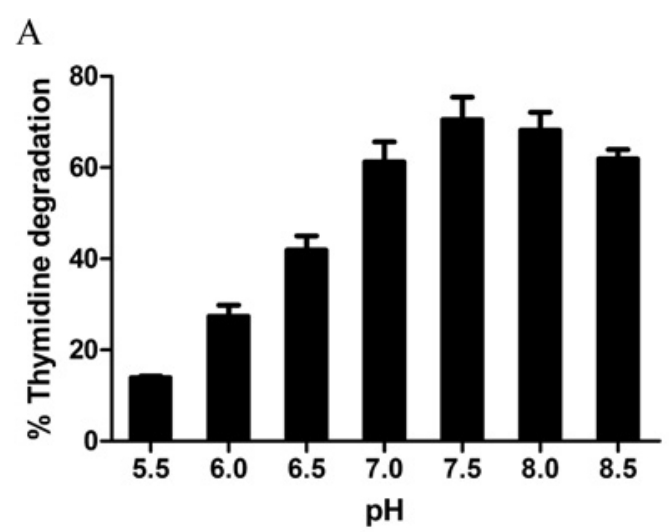

B

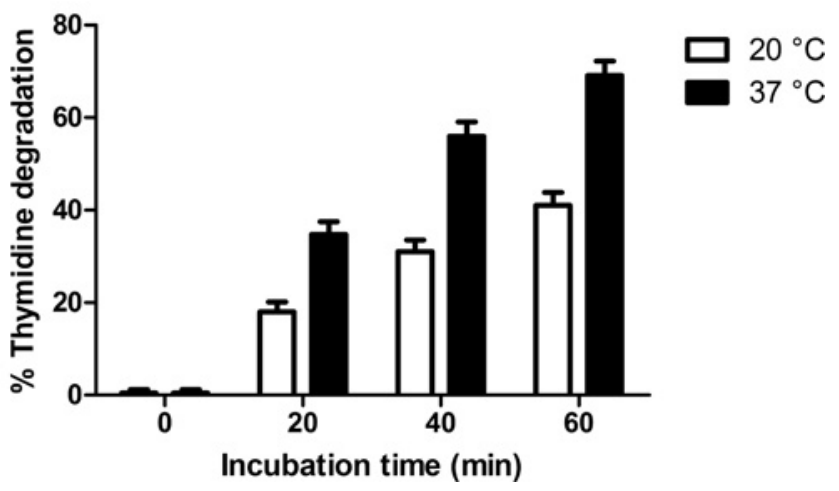

Figure $1 \mathrm{pH}$ and temperature dependence of $\mathrm{TP}_{\mathrm{Hyor}}$-mediated $\mathrm{dThd}$ phosphorolysis

(A) $\mathrm{pH}$-dependent dThd $(100 \mu \mathrm{M})$ degradation after a 60 min incubation in the presence of $\mathrm{TP}_{\text {Hyor. }}$ (B) Temperature-dependent dThd $(100 \mu \mathrm{M})$ degradation after a 60 min incubation in the presence of $\mathrm{TP}_{\text {Hyor }}$. Results are the means \pm S.D. of two independent experiments.

Table 2 Substrate specificity of $\mathrm{TP}_{\text {Hyor }}$ for pyrimidine nucleosides and nucleoside analogues

\begin{tabular}{|c|c|}
\hline Substrate for $\mathrm{TP}_{\text {Hyor }}$ & No substrate for $\mathrm{TP}_{\text {Hyor }}$ \\
\hline \multicolumn{2}{|c|}{ Natural pyrimidine nucleosides } \\
\hline dThd & Cytidine \\
\hline dUrd & Deoxycytidine \\
\hline Urd & \\
\hline \multicolumn{2}{|c|}{ Pyrimidine nucleoside analogues } \\
\hline 5-Trifluoromethyl-dUrd & $2^{\prime}, 2^{\prime}$-Difluoro-2'-deoxycytidine \\
\hline 5-Fluoro-dUrd & $2^{\prime}, 2^{\prime}$-Difluoro-2'-deoxyuridine \\
\hline 5-Chloro-dUrd & Ara-U \\
\hline 5-Bromo-dUrd & Ara-T \\
\hline 5-lodo-dUrd & BVDU $^{*}$ \\
\hline 5-Fluoro-Urd & AZT \\
\hline 5-lodo-Urd & D4T \\
\hline & 6-Azauridine \\
\hline
\end{tabular}

*Very poor phosphorolysis of BVDU was observed at the highest enzyme concentration.

analysis and are displayed in Table 3 . The specificity constant $\left(k_{\text {cat }} / K_{\mathrm{m}}\right)$ was calculated as an estimate for the catalytic efficiency of the enzyme. Remarkably, the $\mathrm{TP}_{\mathrm{Hyor}}$-mediated phosphorolysis of Urd $\left(K_{\mathrm{m}}=92 \mu \mathrm{M}, k_{\text {cat }} / K_{\mathrm{m}}=0.092\right)$ was found to be almost twice as efficient when compared with dThd $\left(K_{\mathrm{m}}=473 \mu \mathrm{M}, \quad k_{\mathrm{cat}} / K_{\mathrm{m}}=0.046\right)$ and dUrd $\left(K_{\mathrm{m}}=578 \mu \mathrm{M}\right.$, $\left.k_{\text {cat }} / K_{\mathrm{m}}=0.043\right)$. 
Table 3 Kinetic parameters of $\mathrm{TP}_{\text {Hyor }}$

The $K_{m}$ and $k_{\text {cat }}$ values for the natural substrates ( \pm S.E.M.) were computationally determined using non-linear regression analysis (using GraphPad Prism 5) from data obtained in four (dThd and dUrd) or three (Urd) independent experiments. The kinetic parameters for the other compounds were derived from data obtained in two independent experiments.

\begin{tabular}{lccl}
\hline Substrate & $K_{\mathrm{m}}(\mu \mathrm{M})$ & $k_{\text {cat }}\left(\mathrm{s}^{-1}\right)$ & $k_{\text {cat }} / K_{\mathrm{m}}\left[(\mathrm{s} \cdot \mu \mathrm{M})^{-1}\right]$ \\
\hline Natural substrates & & \\
$\quad$ dThd & & & \\
dUrd & $473 \pm 25$ & $21.6 \pm 0.5$ & 0.046 \\
$\quad$ Urd & $578 \pm 29$ & $24.6 \pm 0.5$ & 0.043 \\
Nucleoside analogues & $92 \pm 8$ & $8.5 \pm 0.2$ & 0.092 \\
$\quad$ 5-Fluoro-dUrd & $169 \pm 9$ & $11.9 \pm 0.2$ & 0.070 \\
5-lodo-dUrd & $144 \pm 25$ & $9.5 \pm 0.6$ & 0.066 \\
5-Fluoro-Urd & $47 \pm 4$ & $6.1 \pm 0.1$ & 0.130 \\
5-lodo-Urd & $69 \pm 7$ & $6.4 \pm 0.2$ & 0.093 \\
Pi & & & \\
Co-substrate dThd & $797 \pm 107$ & $17.5 \pm 0.6$ & 0.022 \\
Co-substrate Urd & $388 \pm 43$ & $8.6 \pm 0.2$ & 0.022 \\
& & & \\
\hline
\end{tabular}

When dThd or Urd were added at fixed saturating substrate concentrations and the inorganic phosphate concentration was varied in the reaction mixture, an identical phosphorolytic efficacy $\left(k_{\mathrm{cat}} / K_{\mathrm{m}}=0.022\right.$ ) was found for inorganic phosphate in the presence of either nucleoside substrate (Table 3).

\section{Substrate specificity of $\mathrm{TP}_{\text {Hyor }}$ for nucleoside analogues}

Next, the substrate specificity and kinetic parameters for a variety of antiviral and antitumour nucleoside analogues were determined (Tables 2 and 3). TFT (5-trifluoromethyl-dUrd) and the 5-halogenated dThd and Urd analogues were found to be efficient substrates for $\mathrm{TP}_{\mathrm{Hyor}}$-mediated phosphorolysis. In contrast, BVDU, an excellent substrate for human and $E$. coli $\mathrm{TP}$, was only poorly recognized by the mycoplasma-derived enzyme $(<5 \%$ BVU formation from BVDU compared with $\sim 66 \%$ Thy formation from dThd after a $10 \mathrm{~min}$ incubation under identical reaction conditions). Also ara-T (Thy arabinoside) and ara-U (Ura arabinoside), and the anti-HIV agents AZT (azidothymidine/zidovudine) and D4T (stavudine) which are not a substrate for human and E. coli $\mathrm{TP}$, were not converted by $\mathrm{TP}_{\text {Hyor }}$. Whereas the glycosidic bond of the riboside analogue 5-fluoro-Urd was efficiently cleaved by this enzyme, the cytostatic antimetabolite drug 6-azauridine was not susceptible to phosphorolysis by $\mathrm{TP}_{\mathrm{Hyor}}$. As expected, the difluorinated cytidine analogue gemcitabine $\left(2^{\prime}, 2^{\prime}\right.$-difluoro- $2^{\prime}$ deoxycytidine $)$ as well as its deaminated metabolite $2^{\prime}, 2^{\prime}$-difluoro- $2^{\prime}$-deoxyuridine were not cleaved either (Table 2).

Overall, the 5-halogenated thymidine analogues 5-fluoro-dUrd (floxuridine) and 5-iodo-dUrd (idoxuridine), which represent clinically approved drugs for the treatment of cancer and herpesvirus infections respectively, were found to be better substrates for $\mathrm{TP}_{\mathrm{Hyor}}$ than dThd. Likewise, $\mathrm{TP}_{\mathrm{Hyor}}$-catalysed phosphorolysis of the Urd analogues 5-fluoro-Urd and 5-iodoUrd was found to proceed more efficiently when compared with Urd. In general, Urd and its analogues were found to be preferred substrates over dThd and its analogues (Table 3).

\section{dThd and Urd compete for phosphorolysis by $\mathrm{TP}_{\text {Hyor }}$}

Since the enzymatic parameters demonstrated a more efficient $\mathrm{TP}_{\mathrm{Hyor}}$-mediated phosphorolysis of Urd when compared with dThd, we next investigated whether both natural substrates are

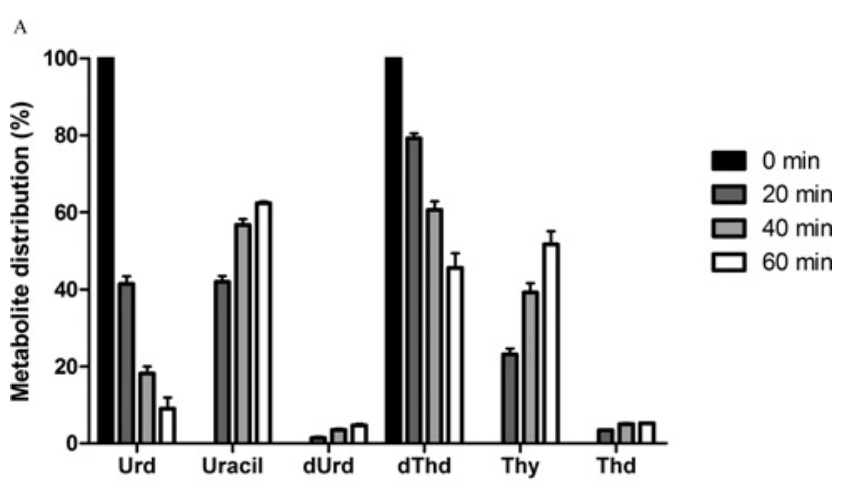

B
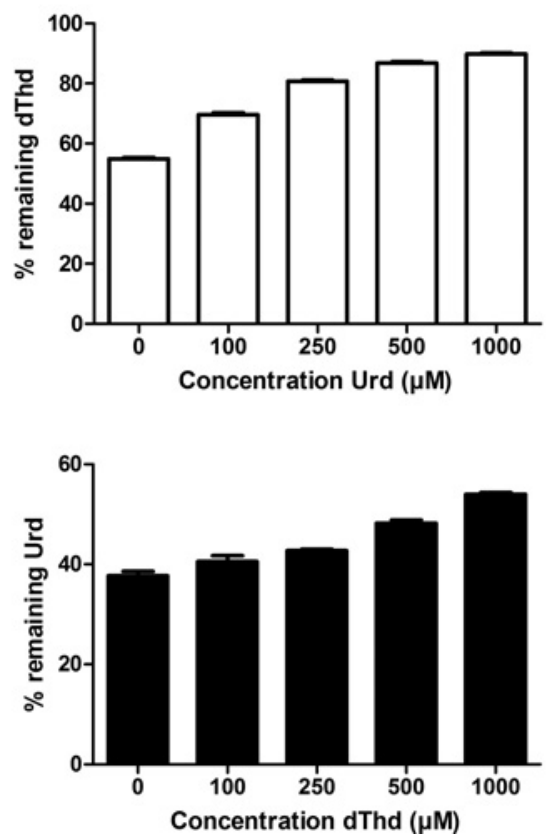

Figure 2 Competition for $\mathrm{TP}_{\mathrm{Hyor}}$-mediated phosphorolysis

(A) $\mathrm{TP}_{\text {Hyor }}$-mediated metabolite formation from an equimolar mixture of Urd and dThd. (B) $\mathrm{TP}_{\text {Hyor }}$-mediated phosphorolysis of a fixed dThd $(100 \mu \mathrm{M})$ concentration in the presence of varying Urd concentrations after a 30 min incubation. (C) TP $\mathrm{Hyor}_{\text {Hor }}$-mediated phosphorolysis of a fixed Urd $(100 \mu \mathrm{M})$ concentration in the presence of varying dThd concentrations after a $30 \mathrm{~min}$ incubation. Results are the means + S.D. of two independent experiments.

mutually exclusive or can be concomitantly used as a substrate by the enzyme. In a first set of experiments, dThd and Urd were mixed at equimolar concentrations $(100 \mu \mathrm{M})$ and simultaneously incubated with the enzyme. Metabolite formation was then monitored as a function of time. As shown in Figure 2(A), both dThd and Urd were time-dependently converted into their respective base with Urd being more efficiently cleaved than dThd. After a 60 min concomitant incubation of both substrates with the enzyme, $\sim 90 \%$ of the supplied Urd and only $\sim 50 \%$ of the supplied dThd were converted. In addition, Ura and Thy were found to be coupled again with the (deoxy)ribose moieties (derived from Urd and dThd) in an anabolic reaction mediated by $\mathrm{TP}_{\mathrm{Hyor}}$, resulting in the formation of $2^{\prime}$-deoxyuridine (2-dRib-1-P and Ura) and thymine riboside (Rib-1-P and Thy).

In a second set of experiments, a fixed concentration of dThd $(100 \mu \mathrm{M})$ was incubated for $30 \mathrm{~min}$ with the enzyme in the presence of different Urd concentrations. In analogy, $100 \mu \mathrm{M}$ Urd was incubated in the presence of different dThd concentrations for $30 \mathrm{~min}$. Urd dose-dependently decreased the phosphorolysis of dThd (Figure 2B). This inhibition occurred more efficiently 


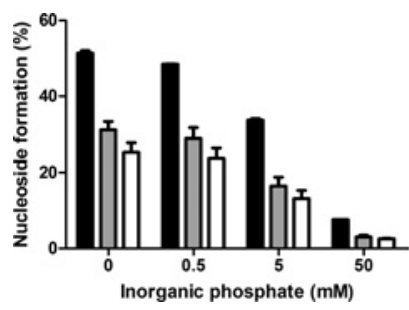

Figure 3 Anabolic activity of $\mathrm{TP}_{\text {Hyor }}$

$\mathrm{TP}_{\text {Hyor }}$-mediated Urd formation from uracil (100 $\left.\mu \mathrm{M}\right)$ and Rib-1-P (1mM); dUrd formation from uracil $(100 \mu \mathrm{M})$ and 2-dRib-1-P $(1 \mathrm{mM})$; and dThd formation from thymine $(100 \mu \mathrm{M})$ and 2-dRib-1-P (1 mM) in the presence of varying $P_{i}$ concentrations after a 20 min incubation at $37^{\circ} \mathrm{C}$. Results are the means + S.D. of two independent experiments.

than the decreased Urd phosphorolysis in the presence of dThd (Figure 2C). Taken together, these results strongly indicate that dThd and Urd compete for the same substrate-binding site.

\section{Urd formation is superior to dThd formation in the anabolic direction of the $\mathrm{TP}_{\text {Hyor }}$ reaction}

The $\mathrm{TP}_{\mathrm{Hyor}}$-mediated coupling of Ura to Rib-1-P and Ura and Thy to 2-dRib-1-P was studied. Urd was more efficiently formed than dUrd and dThd (Figure 3). These findings are in line with the enzymatic parameters determined for the individual substrates and the results obtained in the competition experiments (see above). Nucleoside formation was also found to be highly dependent on the concentration of $\mathrm{P}_{\mathrm{i}}$ present in the reaction mixture, i.e. increasing concentrations of $\mathrm{P}_{\mathrm{i}}$ dose-dependently inhibit the TPcatalysed nucleoside formation (Figure 3 ).

\section{Differential inhibition of $\mathrm{TP}_{\mathrm{Hyor}}$ by known specific TP and UP inhibitors}

The human TP inhibitors TPI and 7-DX were examined for their capacity to inhibit the phosphorolysis of dThd (catalysed by $\mathrm{TP}_{\text {Hyor }}$, human $\mathrm{TP}$ or E. coli $\mathrm{TP}$ ) and Urd (catalysed by $\mathrm{TP}_{\text {Hyor }}$ or UPP1). As shown in Table 4, TPI inhibits the phosphorolysis of dThd catalysed by TP of either mycoplasma, human or E. coli origin in the lower nanomolar range $\left(\mathrm{IC}_{50}=3 \mathrm{nM}, 7 \mathrm{nM}\right.$ and $7 \mathrm{nM}$ respectively). TPI also efficiently inhibits the phosphorolysis of Urd catalysed by $\mathrm{TP}_{\mathrm{Hyor}}\left(\mathrm{IC}_{50}=5 \mathrm{nM}\right)$, but does not inhibit the phosphorolysis of Urd by UPP1 $\left(\mathrm{IC}_{50} \geqslant 500 \mu \mathrm{M}\right)$ (Table 4). The purine-derived TP inhibitor 7-DX was found to inhibit $\mathrm{TP}_{\mathrm{Hyor}}{ }^{-}$ mediated dThd and Urd phosphorolysis in the micromolar range ( $\mathrm{IC}_{50}=60 \mu \mathrm{M}$ and $30 \mu \mathrm{M}$ respectively). A similar inhibitory activity of 7-DX was found against human- and E. coli-derived $\mathrm{TP}\left(\mathrm{IC}_{50}=151 \mu \mathrm{M}\right.$ and $108 \mu \mathrm{M}$ respectively, but a 10 -fold decreased activity was observed towards UPP1-mediated Urd phosphorolysis $\left(\mathrm{IC}_{50}=300 \mu \mathrm{M}\right)$ when compared with $\mathrm{TP}_{\mathrm{Hyor}}$. The well-known UP inhibitor BAU was found to inhibit only the phosphorolysis of Urd catalysed by UPP1 $\left(\mathrm{IC}_{50}=0.89 \mu \mathrm{M}\right)$, but affected neither the efficiency of mycoplasma-, human- or E. coli-catalysed dThd phosphorolysis $\left(\mathrm{IC}_{50}>500 \mu \mathrm{M}\right)$ nor the phosphorolysis of Urd by $\mathrm{TP}_{\text {Hyor }}$. These results indicate that even though $\mathrm{TP}_{\mathrm{Hyor}}$ preferably shows Urd phosphorylase activity, the enzyme behaves catalytically more similar to the TPs.

\section{Computer-assisted molecular modelling}

The complete $M$. hyorhinis genome was recently published for two different strains (strain HUB-1 isolated from swine
Table 4 Inhibition of different phosphorolytic enzymes by inhibitors of human TP and UP

Results are the means \pm S.D. of two independent experiments.

\begin{tabular}{|c|c|c|c|c|c|}
\hline \multirow[b]{3}{*}{ Inhibitor } & \multicolumn{5}{|l|}{$\mathrm{IC}_{50}(\mu \mathrm{M})$} \\
\hline & \multicolumn{3}{|c|}{ Substrate $=\mathrm{dThd}$} & \multicolumn{2}{|l|}{ Substrate $=$ Urd } \\
\hline & $\mathrm{TP}_{\text {Hyor }}$ & Human TP & E. coli TP & $\mathrm{TP}_{\text {Hyor }}$ & UPP1 \\
\hline $\begin{array}{l}\text { TPI } \\
7-D X \\
\text { BAU }\end{array}$ & $\begin{array}{l}0.003 \pm 0.001 \\
\quad 60 \pm 5 \\
>500\end{array}$ & $\begin{array}{l}0.007 \pm 0.001 \\
151 \pm 33 \\
>500\end{array}$ & $\begin{array}{l}0.007 \pm 0.001 \\
108 \pm 0.7 \\
>500\end{array}$ & $\begin{array}{l}0.005 \pm 0.0007 \\
30 \pm 3 \\
>500\end{array}$ & $\begin{array}{l}\geqslant 500 \\
301 \pm 71 \\
0.89 \pm 0.02\end{array}$ \\
\hline
\end{tabular}

respiratory tract [22] and strain MCLD derived from a primary human melanoma cell culture [29]). The protein sequence of TP was found to be highly conserved in both $M$. hyorhinis strains (identical sequence, with the exception of $\mathrm{Ser}^{240}$ in HUB-1 compared with $\mathrm{Phe}^{240}$ in MCLD). In contrast, no putative $U P$ gene was annotated in these mycoplasma strains.

A multiple sequence alignment of $\mathrm{TP}_{\mathrm{Hyor}}$ (Figure 4A) with similar enzymes whose three-dimensional structures have been solved and are deposited in the PDB revealed that $\mathrm{TP}_{\text {Hyor }}$ has sequence identities of $35 \%$ and $40 \%$ respectively, with E. coli (over 440 amino acids) and human TP (over 273 amino acids) and of $46 \%$ and $42 \%$ respectively, with the PyNP of Geobacillus stearothermophilus (over 433 amino acids) and Thermus thermophilus (over 423 amino acids). In all of these enzymes the residues making up the phosphate-binding site and the thymidine-binding site are highly conserved. For this reason our homology-built models of $\mathrm{TP}_{\text {Hyor }}$ (Supplementary Figure S2A at http://www.BiochemJ.org/bj/445/bj4450113add.htm), which basically differ in the ligand-dependent degree of closure of the active site, are considered to be very reliable (the Ramachandran Z-score of -1.87 obtained from WhatCheck [30] means that phi and psi angles for all residues are within the expected ranges for well refined structures). In contrast, a multiple sequence alignment of $\mathrm{TP}_{\text {Hyor }}$ with human UPP1 and E. coli UP (Figure 4B) showed much lower sequence similarity between $\mathrm{TP}_{\text {Hyor }}$ and uridine phosphorylases (pairwise alignment score of $6 \%$ and $3 \%$ respectively), whereas human UPP1 and E. coli UP sequences show a similarity score of $21 \%$.

The almost identical amino acid composition and putative architecture of the active site of $\mathrm{TP}_{\mathrm{Hyor}}$ with respect to human $\mathrm{TP}$ (as shown in Supplementary Figure S3 at http://www.BiochemJ. org/bj/445/bj4450113add.htm) can account for the comparable inhibition of these two enzymes by TPI. In fact, the $\mathrm{Arg}^{202}, \mathrm{Ser}^{217}$ and Lys $^{221}$ side chains that hydrogen bond to the uracil base of TPI in its crystallographic complex with human TP [31], as well as the hydrophobic side chains of $\mathrm{Leu}^{148}$ and $\mathrm{Ile}^{218}$ that stack against the nucleobase ring, are also present in $\mathrm{TP}_{\mathrm{Hyor}}\left(\mathrm{Arg}^{168}, \mathrm{Ser}^{183}\right.$, Lys $^{187}$, Leu ${ }^{114}$ and Ile $^{184}$ respectively) (Supplementary Figure $\mathrm{S} 2 \mathrm{~B}$ ). The same can be said about the catalytic His ${ }^{116}$ in human $\mathrm{TP}$ and $\mathrm{His}^{82}$ in $\mathrm{TP}_{\mathrm{Hyor}}$, which are positionally and functionally equivalent to $\mathrm{His}^{85}$ in $E$. coli TP [32]. These marked similarities, however, cannot explain why $\mathrm{TP}_{\text {Hyor }}$ recognizes Urd as a better substrate than dThd, given that Urd is a very poor substrate, if at all, for human TP.

Interestingly, Lys $^{108}$ in the phosphate-binding pocket of $\mathrm{TP}_{\text {Hyor }}$ (Figure 5) is positionally equivalent to $\mathrm{Lys}^{108}$ in G. stearothermophilus PyNP (PDB code 1BRW), Lys ${ }^{108}$ in Staphylococcus aureus PyNP (PDB code 3H5Q) and Lys ${ }^{107}$ in T. thermophilus (PDB code 2DSJ), but is replaced by $\mathrm{Met}^{142}$ and $\mathrm{Met}^{111}$ respectively, in human (PDB codes 1UOU and 2WK6) and E. coli (PDB codes 2TPT and 1AZY) TP. Likewise, the 
A

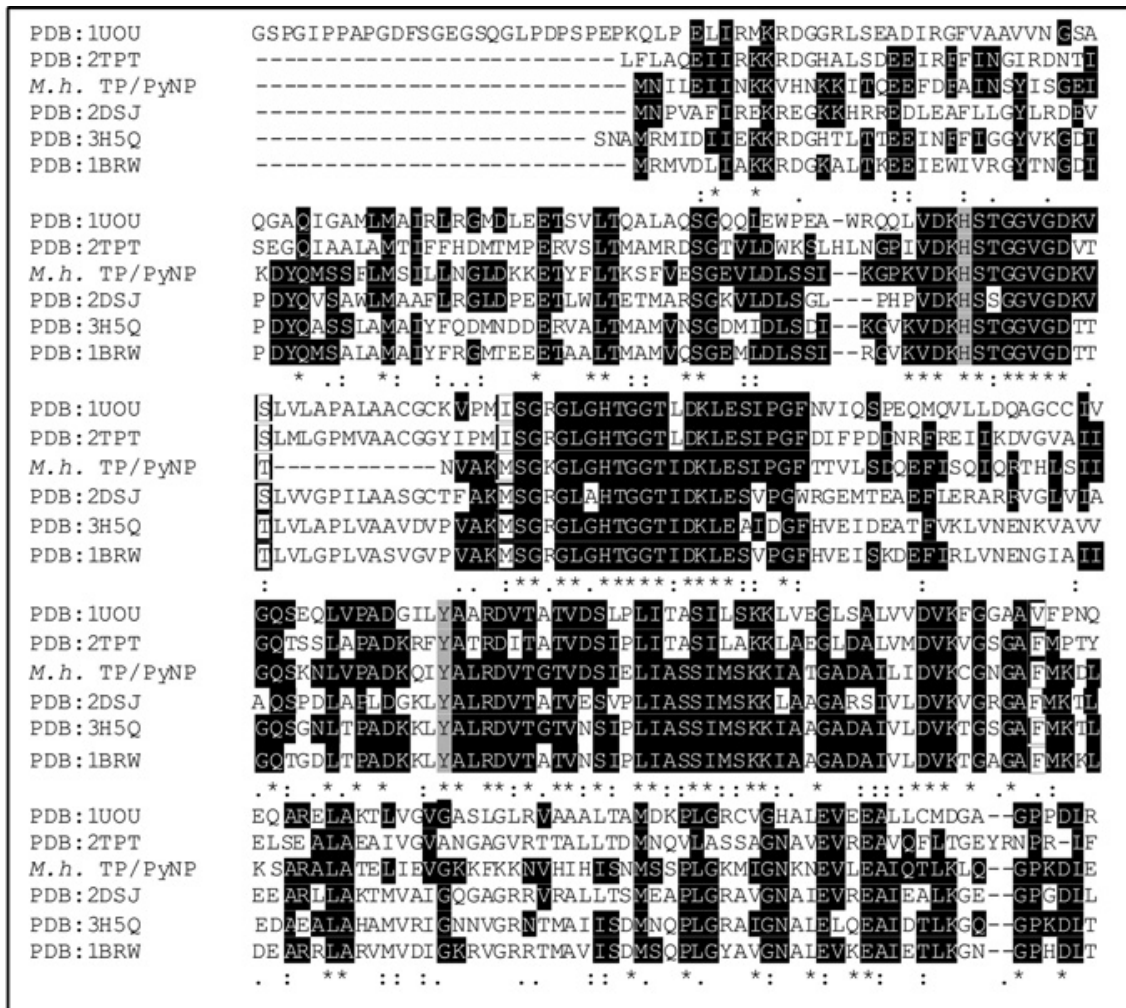

B

Figure 4 Multiple sequence alignment of $\mathrm{TP}_{\mathrm{Hyor}}$ with $\mathrm{PDB}$ entries

(A) TP from E. coli (PDB code 2TPT) and a human source (PDB code 1UOU) and PyNP from T. thermophilus (PDB code 2DSJ), S. aureus (PDB code 3H5Q) and G. stearothermophilus (PDB code 1BRW). Important catalytic residues are formatted in grey and the most significant differences in the substrate-binding site are boxed. (B) UP from E. coli (PDB code 1TGY) and UPP1 (PDB code 3EUE). Black boxes indicate conserved amino acid residues compared with $\mathrm{TP}_{\text {Hyor. }}$. The symbols underneath each block stand for identical amino acids $\left.{ }^{*}\right)$, conserved substitutions (:) and semi-conserved substitutions (.). 


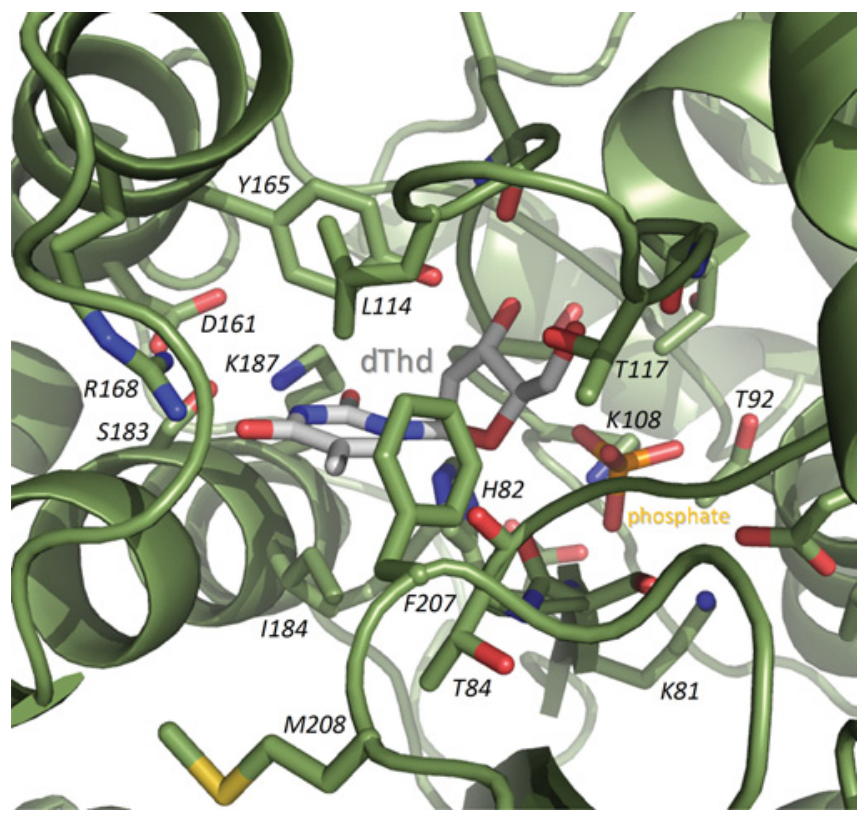

Figure 5 Model of the active site of $\mathrm{TP}_{\text {Hyor }}$

Detail of the active site of the homology-built model of $\mathrm{TP}_{\text {Hyor }}$ showing the putative positions for the nucleoside substrate (dThd) and the attacking phosphate.

position of the neighbouring $\mathrm{Thr}^{92}$ in $\mathrm{TP}_{\mathrm{Hyor}}$ is occupied in the latter two enzymes by a serine (Ser ${ }^{126}$ in human TP and $\mathrm{Ser}^{95}$ in $E$. coli $\mathrm{TP}$ ). It is therefore likely that the nature of the amino acid at these two positions has an influence on transition state formation and/or stabilization of the enzyme-substrate complex during catalysis.

For BAU, there are two X-ray crystal structures available for its complex with $E$. coli UP (PDB code 1U1C) and UPP1 (PDB code $3 E U F)$. The active sites of both enzymes are at the interface between two monomers that, in turn, are part of the "trimer of dimers' that is seen in the crystal structure of the bacterial enzyme. However, many of the residues of E. coli UP and UPP1 that interact with BAU are different in $\mathrm{TP}_{\mathrm{Hyor}}$, and explain why BAU selectively inhibits the E. coli UP and UPP1, but not the UP activity of $\mathrm{TP}_{\text {Hyor }}$. The fact that these two UPs are completely different enzymes from a structural point of view, containing different active site topologies to the TP enzymes, is in agreement with our kinetic observations.

\section{DISCUSSION}

To the best of our knowledge the gene annotated as $T P_{H y o r}$ is the first mycoplasma-encoded phosphorylase to be cloned, expressed and characterized. We provide evidence that the presence of $\mathrm{TP}_{\mathrm{Hyor}}$ in cell cultures due to a mycoplasma infection negatively affects the efficiency of nucleoside analogues used in the treatment of virus infections and cancer. The enzyme shows an unusual substrate selectivity since it catalyses not only the phosphorolysis of dThd and dUrd, but also Urd, which surprisingly turned out to be the preferred substrate. Thus, although the amino acid alignment of $\mathrm{TP}_{\mathrm{Hyor}}$ with human TP, E. coli TP, UPP1 and $E$. coli UP revealed a markedly higher similarity of $\mathrm{TP}_{\mathrm{Hyor}}$ with TP than with UP, the enzyme shows a superior $(\sim 2$-fold) UP catalytic activity. Extensively studied TP enzymes that display, besides TP activity, also UP activity (i.e. TP from human liver, human placenta and mouse liver) have a much lower ( 90-200fold) UP than TP activity, and vice versa, those UP enzymes that also possess TP activity display a much lower ( $\sim 25-160$-fold $)$ associated TP than UP activity [33].

However, early studies on pyrimidine nucleoside phosphorylases isolated from e.g. G. stearothermophilus and Haemophilus influenzae reported comparable TP and UP activities [34,35], as now also shown for $\mathrm{TP}_{\mathrm{Hyor}}$. Such prokaryotic enzymes indeed do not discriminate at the 2 -position of the ribose, and are considered as a separate and well-defined class of pyrimidine nucleoside cleaving enzymes, referred to as PyNP (EC. 2.4.2.2) and ranked within the NP-II family of phosphorolytic enzymes. A similar observation was made for the UP/TP activity of the parasite Giardia lamblia [36]. PyNP and TP are known to display significant sequence similarity and similar physical properties [19]. X-ray crystallography revealed indeed that the three-dimensional structures of $G$. stearothermophilus PyNP and E. coli $\mathrm{TP}$ are very similar $[37,38]$.

From our model of $\mathrm{TP}_{\mathrm{Hyor}}$ it is apparent that this enzyme is structurally related to the PyNP subfamily (NP-II) rather than to the UP subfamily (NP-I) of nucleoside phosphorylases (to which human and E. coli UP belong) [19] (Figure 4). We therefore believe that $\mathrm{TP}_{\mathrm{Hyor}}$, due to both its structural nature and catalytic properties, should be annotated as a NP-II class PyNP to distinguish it from the NP-II class TP and NP-I class UP enzymes.

The data of the present study indicate that one and the same active site in $\mathrm{TP}_{\mathrm{Hyor}} / \mathrm{PyNP}$ is responsible for the phosphorolysis of both dThd and Urd, which is in agreement with the PyNP properties of the enzyme: (i) increasing dThd concentrations decrease Urd phosphorolytic activity and vice versa; (ii) an equimolar mixture of dThd and Urd exposed to $\mathrm{TP}_{\mathrm{Hyor}} / \mathrm{PyNP}$ results in the concomitant formation of dUrd (formed from Urd-derived Ura and dThd-derived 2-dRib-1-P) and the thymine riboside (formed from Urd-derived Rib-1-P and dThd-derived thymine); and (iii) the specific TP inhibitor TPI, being inactive against UPP1, is equally effective in inhibiting $\mathrm{TP}_{\mathrm{Hyor}} / \mathrm{PyNP}$ catalysed phosphorolysis of dThd and Urd.

Inhibitor studies also reveal that, despite its efficient multifunctional activity on dThd/Urd substrates, the nature of $\mathrm{TP}_{\text {Hyor }} / \mathrm{PyNP}$ is much more similar to other TP and PyNP than to UP. TPI is the most potent and selective transition state inhibitor of human TP reported so far. It is currently the subject of clinical trials in combination with TFT to prevent premature breakdown of this anticancer drug to its inactive base [39-41]. We found that TPI is an equally highly potent inhibitor of E. coli TP, human TP and $\mathrm{TP}_{\mathrm{Hyor}} / \mathrm{PyNP}$ that does not inhibit human UPP1. However, by blocking the $\mathrm{TP}_{\mathrm{Hyor}} / \mathrm{PyNP}$ enzyme activity, TPI also annihilates the concomitant UP activity of $\mathrm{TP}_{\mathrm{Hyor}} / \mathrm{PyNP}$. Conversely, BAU, a well-known UP inhibitor that selectively inhibits UPP1 and $E$. coli UP without affecting TP activity $[42,43]$, did not abrogate the UP (and TP) activity of $\mathrm{TP}_{\mathrm{Hyor}} / \mathrm{PyNP}$ and thus discriminates between the mycoplasma UP activity of $\mathrm{TP}_{\mathrm{Hyor}} / \mathrm{PyNP}$ and the human (and E. coli) UP activity.

Although $\mathrm{TP}_{\mathrm{Hyor}} / \mathrm{PyNP}$ was expressed as a recombinant GSTfusion protein, we felt that tagging the nucleoside phosphorylase does not compromise its phosphorolytic activity. Indeed, the specificity constants $\left(k_{\mathrm{cat}} / K_{\mathrm{m}}\right)$ of dThd phosphorolysis by both human TP and human TP-GST were determined using linear regression analysis and were found to be very similar (human TP, $k_{\text {cat }} / K_{\mathrm{m}}=0.036$; human TP-GST, $\left.k_{\text {cat }} / K_{\mathrm{m}}=0.030\right)$. Thus the presence of GST in human TP did not substantially affect the kinetic properties of the enzyme. The catalytic efficiency of GSTtagged $\mathrm{TP}_{\mathrm{Hyor}} / \mathrm{PyNP}$ was found to be in the same range when compared with previously characterized orthologue NPs. The turnover number $\left(k_{\text {cat }}\right)$ of $\mathrm{TP}_{\mathrm{Hyor}} / \mathrm{PyNP}$ was determined as 21.6, 24.6 and $8.5 \mathrm{~s}^{-1}$ for dThd, dUrd and Urd respectively. This compares reasonably well with the turnover numbers of human TP 
for dThd $\left(k_{\text {cat }}=9.4 \mathrm{~s}^{-1}\right)$ and for $H$. influenzae PyNP $\left(k_{\text {cat }}=11.1\right.$, 6.4 and $52.9 \mathrm{~s}^{-1}$ for dThd, dUrd and Urd respectively) $[35,44]$.

The kinetic characterization of $\mathrm{TP}_{\mathrm{Hyor}} / \mathrm{PyNP}$ sheds new light on nucleotide metabolism in mycoplasmas. A potent phosphorolysis of Urd in extracts of mycoplasmas has been described previously $[45,46]$. Originally this activity was attributed to the assumed presence of mycoplasma-encoded UP. This UP activity (measured, for example, by the increased formation of $\left[{ }^{14} \mathrm{C}\right]$ Ura from $\left[{ }^{14} \mathrm{C}\right]$ Urd or the decreased incorporation of $\left[{ }^{3} \mathrm{H}\right]$ Urd in the RNA of infected cell cultures) was even proposed as a tool for the identification of mycoplasma infections in cells $[47,48]$. In contrast with the annotation of a $T P$ and a purine nucleoside phosphorylase gene in the genome of different mycoplasma strains $[22,49]$, no $U P$ gene has been annotated in mycoplasmas to the best of our knowledge. This was also pointed out by Bizarro and Schuck [50] who, in the framework of an in silico study on the purine and pyrimidine nucleotide metabolism in Mollicutes, suggested a TP to be responsible for UP activity. Indeed, the results obtained in the present study indicate that not a UP, but instead a PyNP is responsible for the release of uracil from Urd in mycoplasma cultures. These findings are also in agreement with our data on the cytostatic activity of 5-fluoro-Urd that is markedly decreased in mycoplasma-infected cell cultures, but efficiently restored in the presence of TPI. The phosphorolytic activity of $\mathrm{TP}_{\mathrm{Hyor}} / \mathrm{PyNP}$ against 5-fluoro-Urd could be efficiently blocked by TPI in a cell-free assay (results not shown) pointing again to the UP activity of $\mathrm{TP}_{\mathrm{Hyor}} / \mathrm{PyNP}$ being responsible for 5-fluoro-Urd degradation. The occurrence of a multisubstrate enzyme in mycoplasmas fits the minimal cell and genome concept of mycoplasmas, being the smallest autonomously replicating bacteria, rarely exceeding a genome of $1 \mathrm{Mb}$ [51-53].

Surprisingly, the antiherpetic drug BVDU, a well-known and excellent substrate for human and E. coli TP [26], was hardly acted upon by $\mathrm{TP}_{\mathrm{Hyor}} / \mathrm{PyNP}$. This finding is in agreement with our observation that mycoplasma infection does not compromise the biological (antiviral) activity of BVDU in vitro. Instead, the antiviral activity of BVDU against VV and HSV-2 was found to be slightly (3-5-fold) enhanced in the presence of $\mathrm{TP}_{\mathrm{Hyor}} / \mathrm{PyNP}$. This effect, which could be reversed by administration of the TP inhibitor TPI, may be explained by the $\mathrm{TP}_{\mathrm{Hyor}} / \mathrm{PyNP}$ mediated depletion of intracellular dThd pools, which most likely gives BVDU a competitive advantage for phosphorylation to its biologically active $5^{\prime}$-monophosphate metabolite in mycoplasmainfected cells. Our modelling studies with $\mathrm{TP}_{\mathrm{Hyor}} / \mathrm{PyNP}$ provide a partial explanation for the unexpectedly different behaviour of BVDU as a potential substrate for $\mathrm{TP}_{\mathrm{Hyor}} / \mathrm{PyNP}$, human $\mathrm{TP}$ and E. coli $\mathrm{TP}$ in so far as the 2-bromovinyl group at the 5'position of the uracil ring might be too bulky to fit into the active site of $\mathrm{TP}_{\mathrm{Hyor}} / \mathrm{PyNP}$ due to the presence of the phenyl ring of $\mathrm{Phe}^{207}$, which is positionally equivalent to the smaller $\mathrm{Val}^{241}$ in the human TP enzyme. However, the corresponding $\mathrm{Phe}^{210}$ in the complex of $E$. coli TP with TPI has been shown to change its rotameric state relative to that found in other PyNPs [38]. On the other hand, TPI inhibits $\mathrm{TP}_{\mathrm{Hyor}} / \mathrm{PyNP}$ as efficiently as it inhibits human TP despite the fact that it contains a 5$\mathrm{Cl}$ substituent on the uracil base that is bioisosteric with the methyl group of thymine in dThd. The observation that BVDU is not a good substrate for $\mathrm{TP}_{\mathrm{Hyor}} / \mathrm{PyNP}$ is important in view of the fact that BVU, the free base of this antiviral agent, is a potent inhibitor of DHP (dihydropyrimidine dehydrogenase) [5456]. Inhibition of the latter enzyme prevents further catabolism of Ura and Thy and, more importantly, of the anticancer agent 5-FU (5-fluorouracil), leading to the accumulation of 5-FU and its concomitant life-threatening toxicity [57-59]. Accordingly, a mycoplasma infection will not affect DHP activity in cancer patients treated with BVDU and 5-FU, and thus will not be expected to increase 5-FU toxicity.

BVDU became somewhat more active against VV and HSV-2, but not HSV-1, infection in the presence of mycoplasmas. This can be explained by the markedly different potencies of antiviral activity of BVDU against the particular viruses and/or different targets of inhibition by BVDU. Indeed, BVDU is far more inhibitory to HSV-1 $\left(\mathrm{EC}_{50}=0.04 \mu \mathrm{M}\right)$ than to HSV-2 and VV $\left(\mathrm{EC}_{50}=1.5\right.$ and $47 \mu \mathrm{M}$ respectively). The molecular mechanisms of action of BVDU against HSV-1 are inhibition of HSV-1 DNA polymerase and incorporation into viral DNA after metabolic conversion into its 5'-mono- and 5'-di-phosphates by HSV-1 thymidine kinase, and to its $5^{\prime}$-triphosphate derivative by cellular enzymes. Instead both VV and HSV-2 encode a thymidine kinase that can only convert BVDU into its 5'-monophosphate derivative, which is known to inhibit thymidylate synthase $[60,61]$. Therefore it is well possible that thymidylate synthase is the molecular target of BVDU for HSV-2 and VV inhibition. In this case, the dTMP (and dTDP and dTTP) pools might be further decreased, resulting in a more favourable inhibition of the virus infection by the lack of sufficient dTTP for DNA synthesis in the presence of PyNPexpressing mycoplasmas.

The present study may have important implications for the treatment of cancer patients or patients suffering from viral infections with nucleoside analogues. Mycoplasmas are known to reside in the human body, causing asymptomatic infections. Also, it is widely accepted that particularly immunocompromised patients, such as those suffering from HIV infections, are prone to secondary infections by mycoplasmas, which are then also found in organs different from their usual habitat [7]. Additionally, an increasing number of studies report on the high preferential colonization of human tumours by mycoplasmas [1017]. Taking these facts into consideration, our findings indicate that the treatment of patients with nucleoside analogues may be compromised by the expression of catabolic enzymes with broad substrate specificity, such as those encoded by mycoplasmas, and could be optimized by the co-administration of a mycoplasmatargeting antibiotic or specific enzyme inhibitors. The unique substrate specificity of $\mathrm{TP}_{\mathrm{Hyor}} / \mathrm{PyNP}$ towards natural nucleosides and nucleoside analogues indicates that the design of such a specific mycoplasma PyNP inhibitor could be a feasible goal. We would suggest extending the structure of TPI to allow interaction with the phosphate-binding site in $\mathrm{TP}_{\mathrm{Hyor}} / \mathrm{PyNP}$ where Lys ${ }^{108}$ and $\mathrm{Thr}^{92}$ are found instead of $\mathrm{Met}^{142}$ and $\mathrm{Ser}^{126}$ in human TP. These conserved amino acid differences may underlie the substrate preferences reported above and could be exploited for specific inhibitor design.

\section{AUTHOR CONTRIBUTION}

Johan Vande Voorde participated in the design of the study, carried out the cell culture experiments, sequence alignments and enzyme experiments and participated in the writing of the paper; Federico Gago performed sequence alignments and modelling; Kristof Vrancken contributed to the cloning of the $T P_{\text {Hyor }} / P y N P$ gene and to the purification of the enzyme; Sandra Liekens and Jan Balzarini designed and supervised the study and participated in the writing of the paper. All of the authors read and approved the final paper prior to submission.

\section{ACKNOWLEDGEMENTS}

We thank Christiane Callebaut, Eef Meyen, Kristien Minner, Leentje Persoons, Ria Van Berwaer and Peter Vervaeke for their excellent technical assistance, Dr Tarmo Roosild (Nevada Cancer Institute, Las Vegas, NV, U.S.A.) for generously providing human uridine phosphorylase and Professor Vern Schramm (Albert Einstein College of Medicine, New York, NY, U.S.A.) for kindly providing TPI. 


\section{FUNDING}

This work was supported by the Institute for the Promotion of Innovation through Science and Technology in Flanders (IWT-Vlaanderen) (to J.V.V.), the 'Fonds voor Wetenschappelijk Onderzoek (FWO) Vlaanderen' [grant number G.0486.08] and the K.U. Leuven [grant number PF 10/18].

\section{REFERENCES}

1 Galmarini, C. M., Mackey, J. R. and Dumontet, C. (2002) Nucleoside analogues and nucleobases in cancer treatment. Lancet Oncol. 3, 415-424

2 De Clercq, E. (2004) Antivirals and antiviral strategies. Nat. Rev. Microbiol. 2, 704-720

3 Bronckaers, A., Balzarini, J. and Liekens, S. (2008) The cytostatic activity of pyrimidine nucleosides is strongly modulated by Mycoplasma hyorhinis infection: implications for cancer therapy. Biochem. Pharmacol. 76, 188-197

4 Jetté, L., Bissoon-Haqqani, S., Le François, B., Maroun, J. A. and Birnboim, H. C. (2008) Resistance of colorectal cancer cells to 5 -FUdR and 5-FU caused by mycoplasma infection. Anticancer Res. 28, 2175-2180

5 Liekens, S., Bronckaers, A. and Balzarini, J. (2009) Improvement of purine and pyrimidine antimetabolite-based anticancer treatment by selective suppression of mycoplasma-encoded catabolic enzymes. Lancet Oncol. 10, 628-635

6 Vande Voorde, J., Liekens, S., McGuigan, C., Murziani, P. G., Slusarczyk, M. and Balzarini, J. (2011) The cytostatic activity of NUC-3073, a phosphoramidate prodrug of 5 -fluoro-2'-deoxyuridine, is independent of activation by thymidine kinase and insensitive to degradation by phosphorolytic enzymes. Biochem. Pharmacol. 82, 441-452

7 Razin, S., Yogev, D. and Naot, Y. (1998) Molecular biology and pathogenicity of mycoplasmas. Microbiol. Mol. Biol. Rev. 62, 1094-1156

8 Meyer, R. D. and Clough, W. (1993) Extragenital Mycoplasma hominis infections in adults: emphasis on immunosuppression. Clin. Infect. Dis. 17, S243-S249

9 Wolff, A. J. and O'Donnell, A. E. (2003) HIV-related pulmonary infections: a review of the recent literature. Curr. Opin. Pulm. Med. 9, 210-214

10 Chan, P. J., Seraj, I. M., Kalugdan, T. H. and King, A. (1996) Prevalence of mycoplasma conserved DNA in malignant ovarian cancer detected using sensitive PCR-ELISA. Gynecol. Oncol. 63, 258-260

11 Kidder, M., Chan, P. J., Seraj, I. M., Patton, W. C. and King, A. (1998) Assessment of archived paraffin-embedded cervical condyloma tissues for mycoplasma-conserved DNA using sensitive PCR-ELISA. Gynecol. Oncol. 71, 254-257

12 Huang, S., Li, J. Y., Wu, J., Meng, L. and Shou, C. C. (2001) Mycoplasma infections and different human carcinomas. World J. Gastroenterol. 7, 266-269

13 Pehlivan, M., Itirli, G., Onay, H., Bulut, H., Koyuncuoglu, M. and Pehlivan, S. (2004) Does Mycoplasma sp. play role in small cell lung cancer? Lung Cancer 45, 129-130

14 Pehlivan, M., Pehlivan, S., Onay, H., Koyuncuoglu, M. and Kirkali, Z. (2005) Can mycoplasma-mediated oncogenesis be responsible for formation of conventional renal cell carcinoma? Urology 65, 411-414

15 Yang, H., Qu, L., Ma, H., Chen, L., Liu, W., Liu, C., Meng, L., Wu, J. and Shou, C. (2010) Mycoplasma hyorhinis infection in gastric carcinoma and its effects on the malignant phenotypes of gastric cancer cells. BMC Gastroenterol. 10, 132

16 Apostolou, P., Tsantsaridou, A., Papasotiriou, I., Toloudi, M., Chatziioannou, M. and Giamouzis, G. (2011) Bacterial and fungal microflora in surgically removed lung cancer samples. J. Cardiothorac. Surg. 6, 137

17 Urbanek, C., Goodison, S., Chang, M., Porvasnik, S., Sakamoto, N., Li, C. Z., Boehlein, S. K. and Rosser, C. J. (2011) Detection of antibodies directed at M. hyorhinis p37 in the serum of men with newly diagnosed prostate cancer. BMC Cancer 11, 233

18 McGuigan, C., Murziani, P., Slusarczyk, M., Gonczy, B., Vande Voorde, J., Liekens, S. and Balzarini, J. (2011) Phosphoramidate ProTides of the anticancer agent FUDR successfully deliver the preformed bioactive monophosphate in cells and confer advantage over the parent nucleoside. J. Med. Chem. 54, 7247-7258

19 Pugmire, M. J. and Ealick, S. E. (2002) Structural analyses reveal two distinct families of nucleoside phosphorylases. Biochem. J. 361, 1-25

20 Fukushima, M., Suzuki, N., Emura, T., Yano, S., Kazuno, H., Tada, Y., Yamada, Y. and Asao, T. (2000) Structure and activity of specific inhibitors of thymidine phosphorylase to potentiate the function of antitumor 2 '-deoxyribonucleosides. Biochem. Pharmacol. $\mathbf{5 9}$, 1227-1236

21 Balzarini, J., Gamboa, A. E., Esnouf, R., Liekens, S., Neyts, J., De Clercq, E., Camarasa, M. J. and Pérez-Pérez, M. J. (1998) 7-Deazaxanthine, a novel prototype inhibitor of thymidine phosphorylase. FEBS Lett. 438, 91-95

22 Liu, W., Fang, L., Li, S., Li, Q., Zhou, Z., Feng, Z., Luo, R., Shao, G., Wang, L., Chen, H. and Xiao, S. (2010) Complete genome sequence of Mycoplasma hyorhinis strain HUB-1. J Bacteriol. 192, 5844-5845
23 Liekens, S., Hernández, A. I., Ribatti, D., De Clercq, E., Camarasa, M. J., Pérez-Pérez, M. J. and Balzarini, J. (2004) The nucleoside derivative 5'-0-trityl-inosine (KIN59) suppresses thymidine phosphorylase-triggered angiogenesis via a noncompetitive mechanism of action. J. Biol. Chem. 279, 29598-29605

24 Kelley, L. A. and Sternberg, M. J. (2009) Protein structure prediction on the web: a case study using the Phyre server. Nat. Protoc. 4, 363-371

25 Patterson, A. V., Zhang, H., Moghaddam, A., Bicknell, R., Talbot, D. C., Stratford, I. J. and Harris, A. L. (1995) Increased sensitivity to the prodrug 5'-deoxy-5-fluorouridine and modulation of 5-fluoro-2'-deoxyuridine sensitivity in MCF-7 cells transfected with thymidine phosphorylase. Br. J. Cancer 72, 669-675

26 Desgranges, C., Razaka, G., Rabaud, M., Bricaud, H., Balzarini, J. and De Clercq, E. (1983) Phosphorolysis of (E)-5-(2-bromovinyl)-2'-deoxyuridine (BVDU) and other 5 -substituted-2'-deoxyuridines by purified human thymidine phosphorylase and intact blood platelets. Biochem. Pharmacol. 32, 3583-3590

27 Liermann, B. and Herrmann, G. (1983) (E)-5-(2-Bromovinyl)-2'-deoxyuridine: a good substrate for mammalian pyrimidine nucleoside phosphorylases. Biomed. Biochim. Acta 42, K35-K38

28 Balzarini, J., Sienaert, R., Liekens, S., Van Kuilenburg, A., Carangio, A., Esnouf, R., De Clercq, E. and McGuigan, C. (2002) Lack of susceptibility of bicyclic nucleoside analogs, highly potent inhibitors of varicella-zoster virus, to the catabolic action of thymidine phosphorylase and dihydropyrimidine dehydrogenase. Mol. Pharmacol. 61, 1140-1145

29 Kornspan, J. D., Lysnyansky, I., Kahan, T., Herrmann, R., Rottem, S. and Nir-Paz, R. (2011) Genome analysis of a Mycoplasma hyorhinis strain derived from a primary human melanoma cell line. J. Bacteriol. 193, 4543-4544

30 Rodriguez, R., Chinea, G., Lopez, N., Pons, T. and Vriend, G. (1998) Homology modeling, model and software evaluation: three related resources. Bioinformatics 14, 523-528

31 Norman, R. A., Barry, S. T., Bate, M., Breed, J., Colls, J. G., Ernill, R. J., Luke, R. W., Minshull, C. A., McAlister, M. S., McCall, E. J. et al. (2004) Crystal structure of human thymidine phosphorylase in complex with a small molecule inhibitor. Structure 12, 75-84

32 Mendieta, J., Martin-Santamaria, S., Priego, E. M., Balzarini, J., Camarasa, M. J., Pérez-Pérez, M. J. and Gago, F. (2004) Role of histidine ${ }^{85}$ in the catalytic mechanism of thymidine phosphorylase as assessed by targeted molecular dynamics simulations and quantum mechanical calculations. Biochemistry $\mathbf{4 3}, 405-414$

33 el Kouni, M. H., el Kouni, M. M. and Naguib, F. N. (1993) Differences in activities and substrate specificity of human and murine pyrimidine nucleoside phosphorylases: implications for chemotherapy with 5-fluoropyrimidines. Cancer Res. 53, 3687-3693

34 Saunders, P. P., Wilson, B. A. and Saunders, G. F. (1969) Purification and comparative properties of a pyrimidine nucleoside phosphorylase from Bacillus stearothermophilus. J. Biol. Chem. 244, 3691-3697

35 Scocca, J. J. (1971) Purification and substrate specificity of pyrimidine nucleoside phosphorylase from Haemophilus influenzae. J. Biol. Chem. 246, 6606-6610

36 Lee, C. S., Jiménez, B. M. and O'Sullivan, W. J. (1988) Purification and characterization of uridine (thymidine) phosphorylase from Giardia lamblia. Mol. Biochem. Parasitol. 30 $271-277$

37 Walter, M. R., Cook, W. J., Cole, L. B., Short, S. A., Koszalka, G. W., Krenitsky, T. A. and Ealick, S. E. (1990) Three-dimensional structure of thymidine phosphorylase from Escherichia coli at 2.8 A resolution. J. Biol. Chem. 265, 14016-14022

38 Pugmire, M. J., Cook, W. J., Jasanoff, A., Walter, M. R. and Ealick, S. E. (1998) Structural and theoretical studies suggest domain movement produces an active conformation of thymidine phosphorylase. J. Mol. Biol. 81, 285-299

39 Temmink, O. H., Emura, T., de Bruin, M., Fukushima, M. and Peters, G. J. (2007) Therapeutic potential of the dual-targeted TAS-102 formulation in the treatment 0 gastrointestinal malignancies. Cancer Sci. 98, 779-789

40 Overman, M. J., Kopetz, S., Varadhachary, G., Fukushima, M., Kuwata, K., Mita, A., Wolff, R. A., Hoff, P., Xiong, H. and Abbruzzese, J. L. (2008) Phase I clinical study of three times a day oral administration of TAS-102 in patients with solid tumors. Cancer Invest. 26, 794-799

41 Overman, M. J., Varadhachary, G., Kopetz, S., Thomas, M. B., Fukushima, M., Kuwata, K., Mita, A., Wolff, R. A., Hoff, P. M., Xiong, H. and Abbruzzese, J. L. (2008) Phase 1 study of TAS-102 administered once daily on a 5 -day-per-week schedule in patients with solid tumors. Invest. New Drugs 26, 445-454

42 Niedzwicki, J. G., Chu, S. H., el Kouni, M. H., Rowe, E. C. and Cha, S. (1982) 5-Benzylacyclouridine and 5-benzyloxybenzylacyclouridine, potent inhibitors of uridine phosphorylase. Biochem. Pharmacol. 31, 1857-1861

43 Park, K. S., el Kouni, M. H., Krenitsky, T. A., Chu, S. H. and Cha, S. (1986) Inhibition of uridine phosphorylase from Escherichia coli by benzylacyclouridines. Biochem. Pharmacol. 35, 3853-3855

44 Finnis, C., Dodsworth, N., Pollitt, C. E., Carr, G. and Sleep, D. (1993) Thymidine phosphorylase activity of platelet-derived endothelial growth factor is responsible for endothelial cell mitogenicity. Eur. J. Biochem. 212, 201-210

45 McGarrity, G. J., Gamon, L., Steiner, T., Tully, J. and Kotani, H. (1985) Uridine phosphorylase activity among the class Mollicutes. Curr. Microbiol. 12, 107-112 
46 Finch, L. R. and Mitchell, A. (1992) Sources of nucleotides. In Mycoplasmas, Molecular Biology and Pathogenesis (Maniloff, J., McElhany, R., Fynch, L. and Baseman, J., eds), pp. 211-230, ASM Press, Washington, D.C.

47 Levine, E. M. (1972) Mycoplasma contamination of animal cell cultures: a simple, rapid detection method. Exp. Cell Res. 74, 99-109

48 Schneider, E. L., Stanbridge, E. J. and Epstein, C. J. (1974) Incorporation of 3H-uridine and $3 \mathrm{H}$-uracil into RNA: a simple technique for the detection of mycoplasma contamination of cultured cells. Exp. Cell Res. 84, 311-318

49 Tham, T. N., Ferris, S., Kovacic, R., Montagnier, L. and Blanchard, A. (1993) Identification of Mycoplasma pirum genes involved in the salvage pathways for nucleosides. J. Bacteriol. 175, 5281-5285

50 Bizarro, C. V. and Schuck, D. C. (2007) Purine and pyrimidine nucleotide metabolism in Mollicutes. Genet. Mol. Biol. 30, 190-201

51 Mushegian, A. R. and Koonin, E. V. (1996) A minimal gene set for cellular life derived by comparison of complete bacterial genomes. Proc. Natl. Acad. Sci. U.S.A. 93, 10268-10273

52 Glass, J. I., Assad-Garcia, N., Alperovich, N., Yooseph, S., Lewis, M. R., Maruf, M., Hutchison, III, C. A., Smith, H. 0. and Venter, J. C. (2006) Essential genes of a minimal bacterium. Proc. Natl. Acad. Sci. U.S.A. 103, 425-430

53 Kuhner, S., van Noort, V., Betts, M. J., Leo-Macias, A., Batisse, C., Rode, M., Yamada, T., Maier, T., Bader, S., Beltran-Alvarez, P. et al. (2009) Proteome organization in a genome-reduced bacterium. Science 326, 1235-1240

54 Desgranges, C., Razaka, G., De Clercq, E., Herdewijn, P., Balzarini, J., Drouillet, F. and Bricaud, H. (1986) Effect of (E)-5-(2-bromovinyl)uracil on the catabolism and antitumor activity of 5-fluorouracil in rats and leukemic mice. Cancer Res. 46, 1094-1101

Received 23 December 2011/30 March 2012; accepted 4 April 2012

Published as BJ Immediate Publication 4 April 2012, doi:10.1042/BJ20112225
55 Ogura, K., Nishiyama, T., Takubo, H., Kato, A., Okuda, H., Arakawa, K., Fukushima, M., Nagayama, S., Kawaguchi, Y. and Watabe, T. (1998) Suicidal inactivation of human dihydropyrimidine dehydrogenase by (E)-5-(2-bromovinyl)uracil derived from the antiviral, sorivudine. Cancer Lett. 122, 107-113

56 Nishiyama, T., Ogura, K., Okuda, H., Suda, K., Kato, A. and Watabe, T. (2000) Mechanism-based inactivation of human dihydropyrimidine dehydrogenase by (E)-5-(2-bromovinyl)uracil in the presence of NADPH. Mol. Pharmacol. $\mathbf{5 7}$, 899-905

57 Keizer, H. J., De Bruijn, E. A., Tjaden, U. R. and De Clercq, E. (1994) Inhibition of fluorouracil catabolism in cancer patients by the antiviral agent (E)-5-(2-bromovinyl) -2'-deoxyuridine. J. Cancer Res. Clin. Oncol. 120, 545-549

58 Okuda, H., Nishiyama, T., Ogura, K., Nagayama, S., Ikeda, K., Yamaguchi, S., Nakamura, Y., Kawaguchi, K., Watabe, T. and Ogura, Y. (1997) Lethal drug interactions of sorivudine, a new antiviral drug, with oral 5-fluorouracil prodrugs. Drug Metab. Dispos. 25, 270-273

59 Okuda, H., Ogura, K., Kato, A., Takubo, H. and Watabe, T. (1998) A possible mechanism of eighteen patient deaths caused by interactions of sorivudine, a new antiviral drug, with oral 5-fluorouracil prodrugs. J. Pharmacol. Exp. Ther. 287, 791-799

60 Labenz, J., Friedich, D. and Falke, D. (1982) Analysis of the TK enzyme complex induced by HSV types 1 and 2 by means of isoelectric focusing and polyacrylamide gel electrophoresis. Arch. Virol. 71, 235-249

61 Balzarini, J., De Clercq, E., Mertes, M. P., Shugar, D. and Torrence, P. F. (1982) 5-Substituted 2'-deoxyuridines: correlation between inhibition of tumor cell growth and inhibition of thymidine kinase and thymidylate synthetase. Biochem. Pharmacol. 31 3673-3682 


\section{SUPPLEMENTARY ONLINE DATA}

\section{Characterization of pyrimidine nucleoside phosphorylase of Mycoplasma hyorhinis: implications for the clinical efficacy of nucleoside analogues}

Johan VANDE VOORDE* ${ }^{*}$ Federico GAG0 $\dagger$, Kristof VRANCKEN ${ }^{*}$, Sandra LIEKENS ${ }^{* 1}$ and Jan BALZARINI ${ }^{* 1}$

*Rega Institute for Medical Research, KU Leuven, Minderbroedersstraat 10, blok x - bus 1030, B-3000 Leuven, Belgium, and †Departamento de Farmacología, Universidad de Alcalá, E-28871 Alcalá de Henares, Madrid, Spain

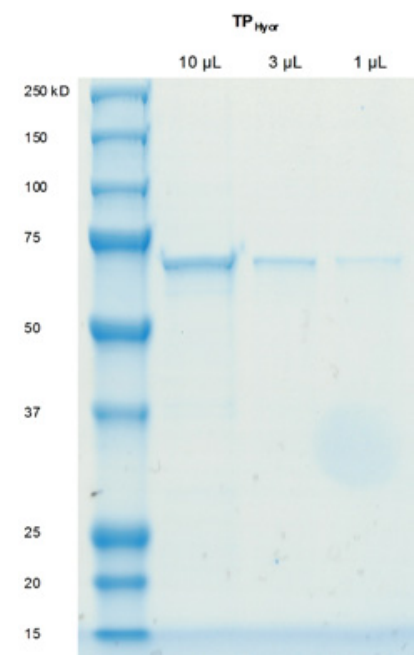

Figure S1 Purity evaluation of the M. hyorhinis TP-GST fusion protein

Three different volumes of the purified enzyme preparation $(10 \mu l, 3 \mu \mathrm{l}$ and $1 \mu \mathrm{l} ; 0.17 \mu \mathrm{g} / \mu \mathrm{l})$ were analysed using SDS/PAGE to evaluate the purity of the sample. Proteins were stained using Bio-Safe ${ }^{\mathrm{TM}}$ Coomassie G-250 Stain (Bio-Rad Laboratories). Molecular mass is given on the left-hand side in $\mathrm{kDa}$.

\footnotetext{
${ }^{1}$ Correspondence may be addressed to either of these authors (email jan.balzarini@rega.kuleuven.be or sandra.liekens@rega.kuleuven.be).
} 

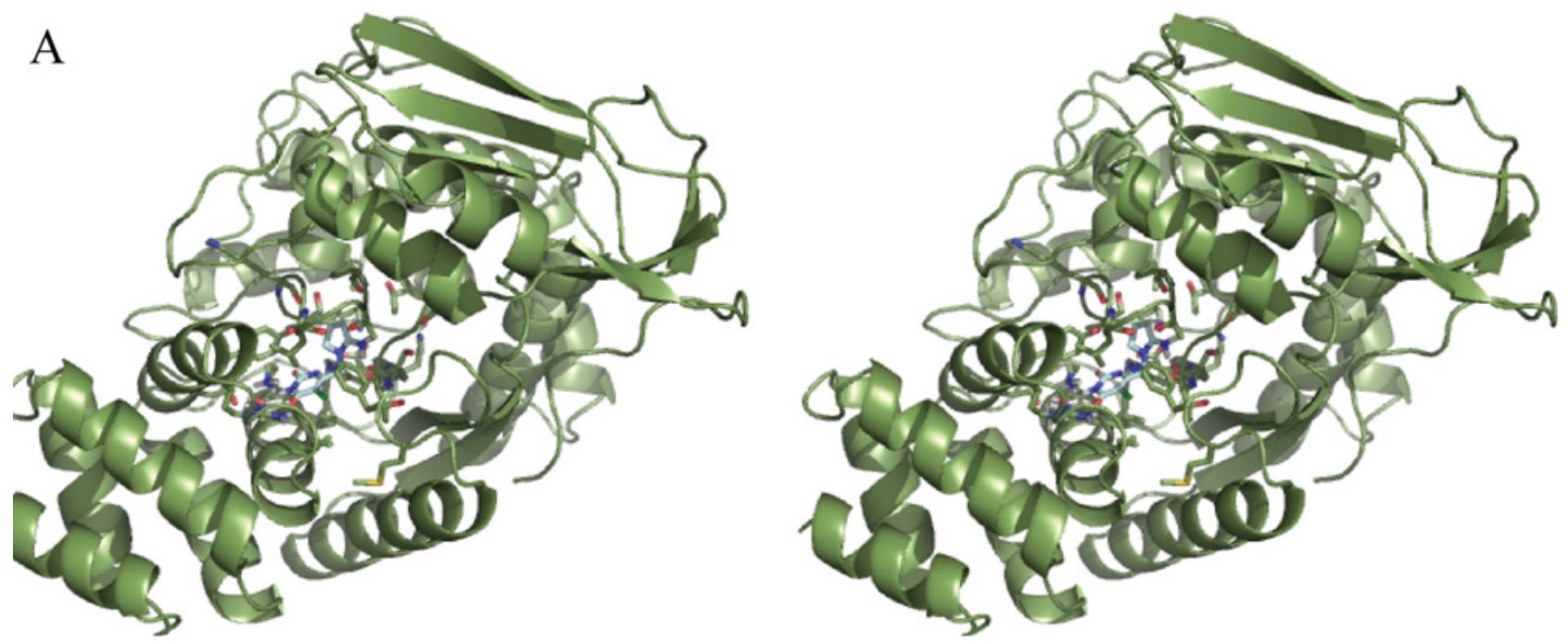

$\mathrm{B}$

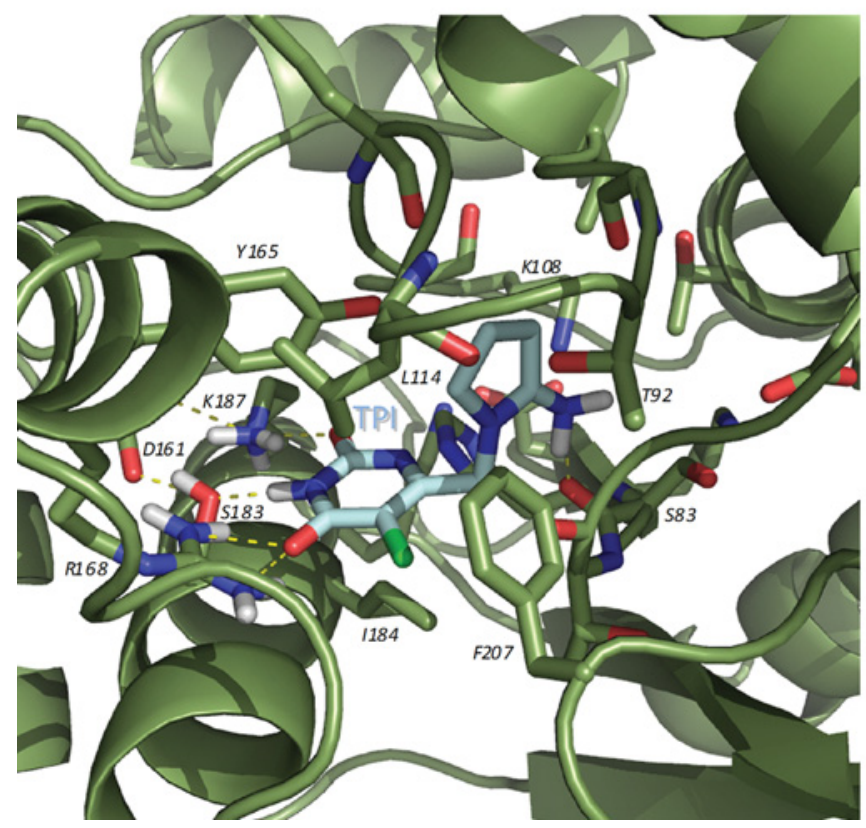

Figure S2 Homology model of $\mathrm{TP}_{\mathrm{Hyor}}$ in complex with TPI

(A) Stereoview of a cartoon representation of TPHyor (C atoms in dark green) in complex with TPI (C atoms in blue). (B) Detailed view of (A). The uracil base of TPI (C atoms, cyan; $\mathrm{N}$ atoms, blue; and 0 atoms, red) is sandwiched between the hydrophobic side chains of Leu"14 (above) and $\| e^{184}$ (below), and held in place by hydrogen bonds (yellow broken lines) to the side chains of Arg ${ }^{168}$, $\mathrm{Ser}^{183}$ and Lys ${ }^{187}$ (stabilized by the carboxylate of $\mathrm{Asp}^{161}$ ), whereas the amino group on the pyrrolidine ring forms a strong hydrogen bond with the backbone carbonyl of Ser ${ }^{83}$. Phe ${ }^{207}$ appears in the foreground, just in front of the 5-chlorine substituent on the uracil that is isosteric with the methyl group of thymine in the dThd substrate (not shown). 


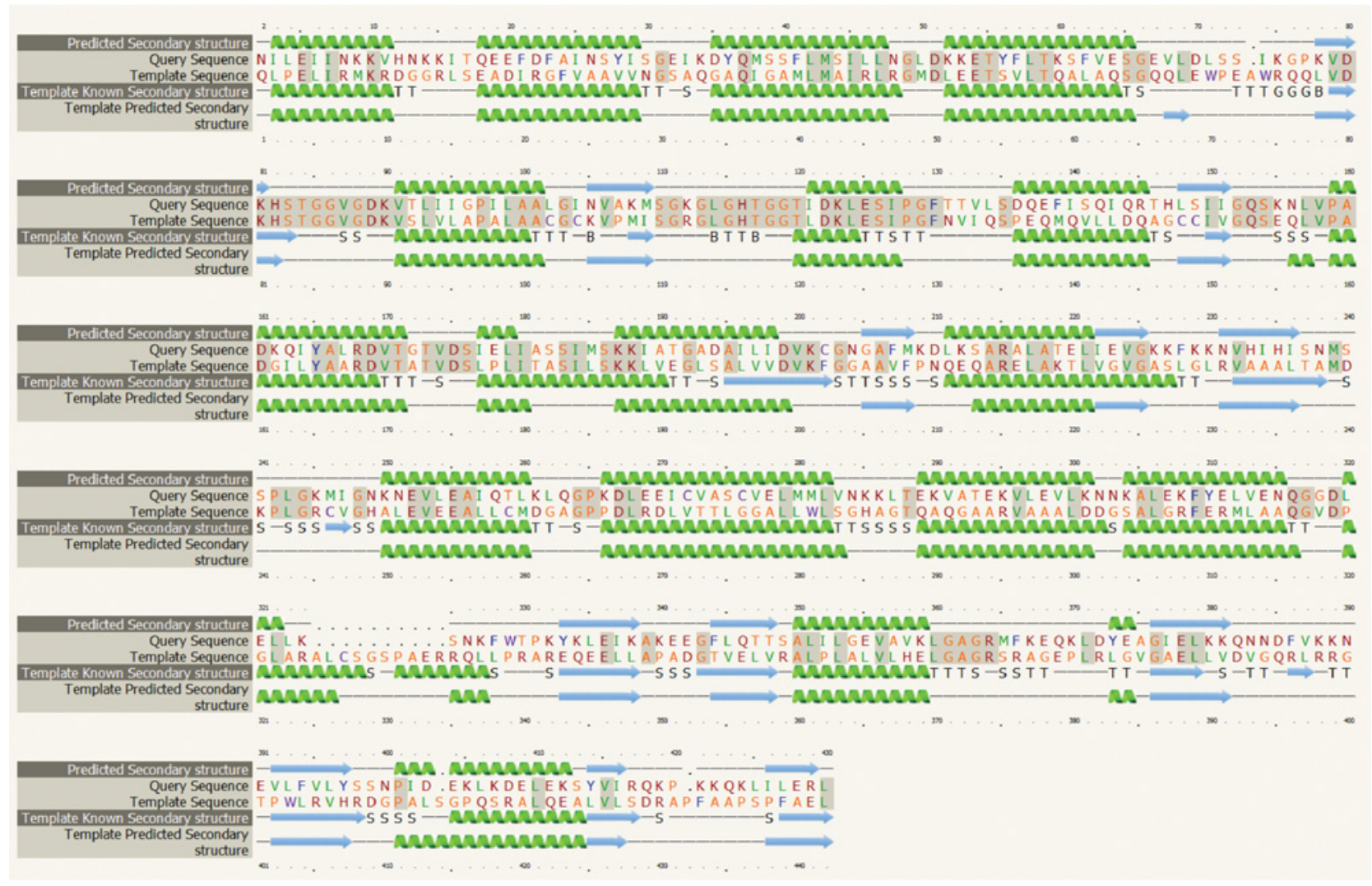

Figure S3 Sequence alignment and secondary structure prediction for $\mathrm{TP}_{\mathrm{Hyor}}$ using human $\mathrm{TP}$ as the template

The predicted (Phyre ${ }^{2}$ server) secondary structure (green $\alpha$-helices and blue $\beta$-sheets) of $\mathrm{TP}_{\text {Hyor }}$ closely resembles the known secondary structure of human TP.

Received 23 December 2011/30 March 2012; accepted 4 April 2012

Published as BJ Immediate Publication 4 April 2012, doi:10.1042/BJ20112225 